\title{
BARSKI TRGOVCI U DUBROVNIKU OD 1358. DO 1405. GODINE
}

\author{
Marijan PREMOVIĆ \\ Filozofski fakultet Univerziteta Crne Gore \\ Nikšić, Crna Gora
}

\author{
UDK: 339: 94(497.5 Dubrovnik)“1358/1405“ \\ DOI: $10.21857 /$ y54jofk7jm \\ Izvorni znanstveni rad \\ Prihvaćeno: 17. ožujak 2021.
}

U radu se razmatra trgovačko djelovanje Barana u Dubrovniku u razdoblju od 1358. do 1405. godine. Istraživanje je zasnovano na raščlambi građe iz Državnog arhiva u Dubrovniku (ser. 26 Diversa Notariae, ser. 35 Diversa Cancellariae i ser. 36 Debita Notariae) i povijesne literature. U prvom dijelu rada u općim se crtama prikazuju političke prilike, prisutnost i djelovanje Barana u Dubrovniku, ukazuje na gospodarske mogućnosti dolaska u Grad i način uzimanja kredita (kreditna jamstva: jamci i zalozi, prokuratori, rokovi vraćanja kredita i kamatne stope). U drugom se dijelu tragom spomenute arhivske građe prati mikropovijest kreditnih zaduženja barskih trgovaca u Gradu sv. Vlaha. Navedena su najvažnija imena barskih dužnika, učestalost njihovih dolazaka, boravci, kreditna zaduženja, kada i koliko su se zadužili, važnija imena kreditora, trgovački oblici djelovanja i gospodarske mogućnosti poslovanja u Dubrovniku. Prezentirane su trgovačke karijere i aktivnosti pojedinih trgovaca, kao i prisutnost barskih rodova i obitelji u kreditnoj trgovini Grada. Proučava se intenzitet kreditne trgovine te predstavlja promet i analiza gospodarske povijesti Bara, kroz interpretaciju vrela iz dubrovačkog arhiva.

Ključne riječi: Bar, Dubrovnik, kreditna trgovina, trgovački proizvodi, trgovačka društva, XIV. stoljeće.

\section{UVOD}

Izrada ovog rada zasnovana je na raščlambi izvorne građe iz Državnog arhiva u Dubrovniku, koji je po važnosti jedan od najznačajnijih na Mediteranu. Izuzetno važno mjesto zauzima po količini, starosti i vrijednosti gradiva. ${ }^{1}$ Građa koju smo koristili sadržana je u serijama Notarske zadužnice (Debita Notariae), Različiti spisi kancelarije (Diversa Cancellariae) i Različiti notarski spisi (Diversa Notariae). Dokumenti koje smo pronašli o barskim trgovcima vrlo su brojni,

1 Vidjeti: Vinko Foretić, Dubrovački arhiv u srednjem vijeku, Anali Historijskog instituta Jugoslavenske akademije znanosti i umjetnosti u Dubrovniku, Dubrovnik, sv. 6 - 7, 1959., 315 - 336; Vinko Foretić, O Dubrovačkom arhivu, Arbivist, god. 19, br. 1, Beograd, 1969., 52 - 64; Ilija Mitić, Dubrovačka Republika i njezin arhiv - dva značajna fenomena evropske povijesti, Pomorski zbornik, sv. 23, Rijeka, 1985., 629 - 639. 
pružaju bogatstvo sadržaja za istraživačko praćenje i prikaz njihova kreditnog prometa u Gradu sv. Vlaha.

U istraživanju je zastupljena građa iz svezaka Debita Notariae od broja IV. do broja XIII., a koji obuhvaćaju vremenski raspon od 1358. do 1405. godine. Analiza nije potpuna jer za pojedine godine knjige zaduženja nisu sačuvana u cijelosti. Veći su prekidi između godina 1370. i 1378., 1382. i 1389. te 1396. i 1400 . godine. Od 1405. do 1417 . godine postoji veća praznina, tako da nije moguće prikazati i usporediti pojedina zaduženja Barana tog naznačenog s onim prethodnim razdobljem. ${ }^{2}$ Notarijat pruža veliki broj podataka o kreditiranju trgovine, segmentu koji je bio izuzetno važan za ekonomiju Dubrovnika. Za popis $i$ istraživanje uloge Barana u trgovini ova je serija najvažnija jer je moguće utvrditi imena svih trgovaca angažiranih u trgovini s Gradom. Iz dana u dan moguće je pratiti koliki iznosi se pozajmljuju, zatim imena vjerovnika i dužnika, rok vraćanja i slično. U istraživanju smo rabili gradivo iz serija Diversa Cancellariae i Diversa Notariae. Serija Različiti spisi kancelarije obuhvaća sveske XIX. - XXXV. u razdoblju 1362. - 1372., 1375. - 1376., 1381. - 1383. i 1385. - 1405. godine. Manji je prekid između svezaka XVIII. i XIX., za razdoblje 1356. - 1362. ${ }^{3}$ Fond sadrži dokumente koji se odnose na zadužnice, oglase o prodaji nekretnina, tužbe, ročišta, iskaze svjedoka, presude itd. U zapisima kancelarije nalazimo važne podatke koji nam objašnjavaju pojedine probleme vezane uz kreditnu trgovinu i djelovanje trgovačkih društava. ${ }^{4}$ Fond Notarske zadužnice obuhvaća sveske VII. - XII. u vremenskom razdoblju 1352. - 1358., 1362. - 1379., 1387. - 1391., 1402. - 1408. godine. ${ }^{5}$ U Diversa su upisane sljedeće isprave: zadužnice, mirazi, kupnje i prodaje, oglasi i pozivi o konfiskaciji dužnikove imovine, objave o zapljeni dužnikove imovine ili založni zajmovi itd. ${ }^{6}$ Važno je istaknuti da ni srednjovjekovni notarijat i druga arhivska građa grada Bara, kao ni statut, koliko je poznato, nisu sačuvani. ${ }^{7}$

2 Hrvatska - Državni arhiv u Dubrovniku, Dubrovnik (dalje: HR-DAD), Debita Notariae (dalje: Deb. Not.), ser. 36, sv. $4-13$.

3 HR-DAD, Diversa Cancellariae (Div. Canc.), ser. 35, sv. $19-35$.

4 Ignacij Voje, Kreditna trgovina u srednjovjekovnom Dubrovniku, Sarajevo, 1976., 82 - 84; Esad KURTOvić, Arbivska građa za historiju srednjovjekovne Bosne (Ispisi iz knjiga kancelarije Državnog arhiva u Dubrovniku 1341-1526), knj. 1, Sarajevo, 2019., XI. - XII.

HR-DAD, Diversa Notariae (Div. Not.), ser. 26, sv. 3 - 12.

I. VoJe, Kreditna trgovina, $80-82$.

7 Funkcija notara spominje se 1247., a statut grada Bara prvi se put spominje 1330. godine (svakako je nastao ranije). Savo MAR Ković, Notarijati medievalnih komuna crnogorskog primorja (odrazi antičkog nasljeđa, autonomnosti urbaniteta i humanističkog univerzalizma), Acta Histriae, sv. 18, br. 4, Koper, 2010., $833-834$. 
O ovoj temi nije puno pisano u povijesnoj znanosti. Spomeni kreditne trgovine Barana u Dubrovniku zastupljeni su na nekoliko mjesta u radu Đurđa Boškovića. ${ }^{8}$ Ovaj isječak iz prošlosti Barana nije podrobnije rasvijetljen ni u sintetskoj monografiji o Baru. ${ }^{9}$ I. Voje prikupio je i obradio opsežnu arhivsku građu iz Državnog arhiva u Dubrovniku, pokriveni su uglavnom svi koji se u Gradu pojavljuju ili kao dužnici ili kao kreditori. Među tom opsežnom građom na nekoliko mjesta spominje se samo ukupni kreditni opseg trgovine Barana u pojedinim godinama. Nisu navedena imena dužnika ni vjerovnika, ni kolike kredite uzimaju. Dušanka Dinić-Knežević u svojem radu o Migracijama stanovništva iz južnoslovenskih zemalja u Dubrovnik tokom srednjeg veka ${ }^{10}$ zabilježila je veliki broj Barana koji su se preselili u Dubrovnik. Analizom arhivskih podataka, na nekoliko je mjesta usput spomenula i njihovu kreditnu aktivnost. Korisne podatke o barskom gospodarstvu u XIV. i XV. stoljeću daje istraživanje Bogumila Hrabaka. ${ }^{11} \mathrm{Na}$ osnovu dubrovačke građe Ruža Ćuk prezentirala je trgovačke karijere obitelji Stano i Zare. ${ }^{12}$ Najviše podataka o stanovništvu Bara dao je u novije vrijeme Savo Marković u svojim istraživanjima. Prikazao je barske rodove Nale, Dalmas, Curiacie, Borisi, Menze, Samuelis, Prokulijan i Besali. ${ }^{13}$ Isti autor nastavio je istraživanja o Baru u svojoj opsežnoj i podatcima bogatom radu o Stanovništvu srednjovjekovnog Bara, a na više mjesta posvetio je pažnju trgovini. Prikazao je znatan dio Barana koji se spominju u objavljenim vrelima i neobjavljenoj dubrovačkoj arhivskoj građi iz fondova Oporuke i legati Notarijata

8 Đurđe Boš ković, Stari Bar, Beograd, 1962., 267 - 268, 275 - 276, 279.

9 Sima Ćirković, Bogumil Hrabak, Nikola Damjanović, Đuro Vujović, Bar grad pod Rumijom, Bar, 1984., 21 - 24.

10 Dušanka Dinić-KNežEvić, Migracije stanovništva iz južnoslovenskih zemalja u Dubrovnik tokom srednjeg veka, Novi Sad, 1995., 201 - 209.

11 Bogumil Hrabak, Privreda Bara u XIV i XV veku, Srednjovjekovna istorija Crne Gore kao polje istraživanja, ur. Branislav Kovačević, Podgorica, 1999., 167 - 197.

12 Ruža ĆU K, Dubrovačka porodica Žaretić poreklom iz Bara u srednjem veku, Istoriski časopis, sv. 48, Beograd, 2001., 53 - 57; Ruža Ćuk, Porodica Stano iz Bara u srednjem veku, Istoriski zapisi, sv. 3/4, Podgorica, 1999., $17-25$.

13 Savo Marković, Barski patricijski rod Borisi u prošlosti: Jadran, Evropa, Mediteran, Povijesni prilozi, sv. 28, Zagreb, 2005., 71 - 105; Savo MARKović, “U kriposti suetoga posluxa” - povijest barske patricijske familije Samuelis, Povijesni prilozi, sv. 37, Zagreb, 2009., 191 - 215; Savo MAR Ković, Prilog proučavanju srednjovjekovne latinske leksike, epigrafike i socijalne morfologije Bara: Case Study Cyriacus, Istoriski zapisi, sv. 3/4, Podgorica 2013, 137 - 157; Savo Marković, Žare, Natalis, Dalmas: tri testamenta barskih patricija u Dubrovniku (XV - XVI v.), Arhivski zapisi, sv. 2, Cetinje, 2014., 31 - 60; Savo MAR ković, Barski patriciji Menze (Menče) - prilog poznavanju romansko-slovenske simbioze, Istraživanja, sv. 25, 2014., 89 - 109; Savo MARković: "Per discharigo della consciencia": Testamentarni odrazi medievalnog imaginarija barskog patricijskog roda Natalis (Nalis), Acta Histriae, sv. 3, 2014., 509 - 550. 
serija - Ženidbeni ugovori i mirazi. Iz ovih fondova korištene su serije Oporuka i Ženidbeni ugovori. ${ }^{14}$ Slijedom oporučnih spisa prikazao je prisutnost i djelovanje Baranki u Dubrovniku. ${ }^{15}$

Dosadašnja povijesna saznanja poslužila su kao poticaj za daljnja istraživanja u dubrovačkom arhivu. Na temelju dubrovačkih vrela analizirat ćemo trgovačku karijeru i aktivnosti barskih trgovaca u kreditnoj trgovini Grada u naznačenom razdoblju. Kreditnim transakcijama stječe se cjelovita slika i moguće je praćenje kontinuiteta promatrane problematike. Vrela akcentiraju ekonomsku moć određenih pojedinaca, njihov društveni uspon i razmjere poslovanja, kada je ta suradnja bila najveća, a kada joj je opseg smanjen, o čemu to ovisi u pojedinim periodima, postoji li udruživanje pojedinaca i stvaranje mreže trgovaca i sl. Do adekvatnih zaključaka doći ćemo induktivnom metodom, analitičkim postupkom, uspoređujući dostupne podatke sa statističkog aspekta, s ciljem izvođenja konačne sinteze.

Grad Bar nalazi se na južnom dijelu istočnojadranske obale, u samom podnožju planine Rumije. Udaljen je od morske obale četiri kilometra. Njegova luka, portus Antibarensis, nalazi se kod rta Volujica. Barska komuna obuhvaćala je teritorij (distrikt) preko prijevoja Rumije, Sutormana i Sozine i dopirala do južne obale Skadarskog jezera. ${ }^{16}$ Dubrovnik je zbog svog izvrsnog zemljopisnog položaja na jugu Jadrana, razvoja kreditne trgovine, novčarstva i gospodarskog uspona u XIV. stoljeću privlačio mnoge trgovce iz Bara. ${ }^{17}$ Odabrali smo ovo razdoblje da bismo prikazali trgovačke aktivnosti Barana u dubrovačkoj komuni nakon promjene dubrovačkog političkog statusa, po završetku Zadarskog mira 1358. godine. Te godine prestaje vlast Venecije nad Gradom. Potiskivanjem Mlečana dolazi do većeg razvitka pomorske trgovine Grada i ekonomskog prosperiteta. ${ }^{18}$ Višegradska povelja iz 1359. predstavlja početak procesa prerastanja Dubrovnika od srednjovjekovne komune, uređenog Grada, u Republiku. ${ }^{19}$ S druge strane, Bar 1361. godine dolazi pod vlast zetske obitelji Balšića, koji postaju bliži susjedi

14 Savo Marković, Stanovništvo srednjovjekovnog Bara, Perast, 2014., 304 - 306, 311, 314, 316 - 326, $615,635-638,644-649,668-672,681-682$.

15 Savo Marković, Baranke u Dubrovniku: Matična komuna u izjavama njihove posljednje volje (XIV. - XV. stoljeće), Povijesni prilozi, sv. 46, Zagreb, 2014., 7 - 46.

16 Miloš Antonović, Grad $i$ župa u Zetskom primorju i severnoj Albaniji u XIV $i$ XV veku, Beograd, 2003., 42, 214 - 219; S. MAR Ković, Stanovništvo, 206 - 209.

17 Konstantin JirečE K, Važnost Dubrovnika u trgovačkoj povijesti srednjega vijeka, Dubrovnik, 1915. , $24-33$.

18 Robin Harris, Povijest Dubrovnika, Zagreb, 2006., 59 - 62; Franjo ŠAnJeK, Branka GrbAVAC i sur., Leksikon hrvatskoga srednjovjekovlja, Zagreb, 2017., 192.

19 Zdenka Jane Ković-Römer, Višegradski ugovor: temelj Dubrovačke Republike, Zagreb, $2003 ., 10$ $48,64-68,80-85,90-116$. 
Grada. ${ }^{20}$ Pod njihovom vlašću ostaje do 1405., a od 1412. do 1421. godine Bar se ponovo nalazio pod upravom Balšića. ${ }^{21} \mathrm{Za}$ kronološku granicu uzeli smo 1405. godinu. Tada je došlo do političke promjene i povratka Venecije u Zetu i učvršćenja na južnom dijelu Jadranskog mora. Bar ulazi u mletački Stato da Mar i shodni ekonomski sustav. ${ }^{22}$

\section{BARANI U DUBROVNIKU: OPĆE NAPOMENE O KREDITIMA}

Dubrovnik je bio najveće gospodarsko središte na južnom Jadranu i zbog toga vrlo privlačan stanovništvu zetskog primorja. Bio je atraktivan Baranima koji su željeli preživjeti i zaraditi nešto novca, a i onima koji su težili većem poslovnom uspjehu. $U$ tom kontekstu dolazili su u Dubrovnik. U arhivskim se vrelima spominju mnogi Barani koji u Grad dolaze u potrazi za zaradom te se spominju kao trgovci, prokuratori, obrtnici, sluge, ali i kao svjedoci, svećenici itd. Najbrojniji su bili trgovci. Riječ je planskom useljavanju u Grad, pa najčešće dolaze samostalno i s ciljem rješavanja svoje životne egzistencije. ${ }^{23}$ Mladići iz Bara dolazili su u potrazi za zaradom ili da bi naučili zanat. Ako bi došli s namjerom izučavanja zanata (najčešće obućarskog, zlatarskog, kožarskog ili zidarskog), uglavnom bi ostajali šest, ali ponekad osam i devet godina. ${ }^{24}$ Žene su dolazile da bi našle posao kao služavke. Obvezivale bi se svojim gospodarima na vjernu i marljivu službu, kao i da neće nanijeti štetu domaćinstvu. Rok službe dosezao je i do deset godina. ${ }^{25}$ I muškarci iz Bara dolazili su u Grad da bi služili.

20 Rade Minaljčić, Kraj Srpskog carstva, Beograd, 2001., 51, 59, 62; Božidar ŠE Kularac, Crna Gora u doba Balšića, Cetinje, 2012., 35 - 35.

21 S. MAR Ković, Stanovništvo, $72-73$.

22 Usporedi: Tomislav RAUKAR, Venecija i ekonomski razvoj Dalmacije u XV i XVI stoljeću, Zadarska revija, br. 3 - 4, Zadar, 1976., 177 - 184; Tomislav RAU KAR, Srednjovjekovne ekonomije i hrvatska društva, Zagreb, 2003., 16 - 18.

23 Ivan Božıć, Ekonomski i društveni razvitak Dubrovnika u XIV - XV veku, Istorijski glasnik, sv. 1, Beograd, 1949., 30 - 33; D. Dinić-KnežEvić, Migracije, 50, 81, 87, 89, 121, 138 - 139, 160 161; Usporedi: Tomislav RaukAR, Komunalna društva u Dalmaciji u XV. i u prvoj polovini XVI. stoljeća, Historijski zbornik, god. 25, br. 1, Zagreb, 1982., 139 - 160, 168 - 177.

24 HR-DAD, Div. Not., sv. 9, f. $152^{\prime}$ v (2. i 7. 4. 1376.); sv. 9, f. $216^{\prime}$ v (15. 9. 1379.); Div. Canc., sv. 31, f. 149 'v (10. 1. - 14. 1. 1387.); Div. Not., sv. 10, f. 31v (22. 11. 1388.); Div. Canc., sv. 31, f. 111v (17.7. 1394.); sv. 31, f. 119v (7. 10. 1394.); sv. 31, f. 132v (10.11. 1394.); sv. 31, f. 121v (12. 10. 1394.); sv. 31, f. 159v (12. 5. 1395.); sv. 34, f. 96v (22. 3. 1402.); Div. Not., sv. 11, f. $47^{\prime}$ v (9. 5. 1403.); D. DinićKnežEvić, Migracije, 87, 89; O zanatima u Dubrovniku vidjeti više u: Dragan Rolle R, Dubrovački zanati u XV. i XVI. stoljeću, Zagreb, 1951.

25 HR-DAD, Div. Not., sv. 9, f. 139v (3. 10. 1375.); Div. Canc., sv. 24, f. 160'v (17. 7. 1376.); sv. 27, f. $13 v$ (10. 7. 1387.); sv. 25, f. 159v (10. 12. 1382.); sv. 26, f. 172v (17.3. 1387.); D. DiNić-KNEŽEviĆ, Migracije, 50 - 51 . 
Dolazili su ili pojedinačno, ili u grupi od dva ili tri brata, a neki su doveli i svoje žene i djecu. ${ }^{26} \mathrm{Da}$ su iseljeni Barani i Baranke Grad sv. Vlaha prihvaćali kao svoj novi dom, posvjedočuju nam podatci iz oporuka. To potkrepljujemo primjerima oporuka Mare, supruge Pale Zaulega (1382.), i Maruše, supruge Lukše Benvignute (1391.), ${ }^{27}$ kao i svećenika Pavla Ivanova Grubecicha (1385.). ${ }^{28}$

U srednjem vijeku, kao i danas, trgovci koji nisu imali gotovine bili su prisiljeni posuđivati. Dubrovnik je kao važno trgovačko središte pružao mogućnost davanja gotovinskih zajmova na određeno vrijeme. Roba se najčešće prodavala s odgodom plaćanja, na kredit i uz određenu proviziju. Zbog nedostatka novca mnogi su Barani pribjegavali uzimanju kredita, no to su, uglavnom, radili i svi ostali trgovci. Učestalost prisutnosti Barana u Dubrovniku može se pratiti preko notarske službe. Dubrovačka komuna 1275. donosi odredbu, koja je ušla u njezin statut dvije godine kasnije, da se svi kreditni poslovi koji premašuju vrijednost 10 perpera moraju sklopiti pismeno kod javnog bilježnika. Izravna posljedica te odredbe bila je da je u Grad par godina kasnije stigao školovani notar iz Italije Tomazino de Savere. Njegov dolazak dio je šireg procesa razvoja notarijata, koji je pratio razvoj urbanog društva čiji je dio i aktivna trgovina. ${ }^{29}$ Tomazino de Savere počeo je sukcesivno voditi notarske knjige, a prvi Barani kao dužnici upisani su već 1279 . godine. ${ }^{30} \mathrm{U}$ notarskim bilješkama najčešće se navodi mjesto porijekla trgovaca iz Bara (de Antibaro). U dubrovačkoj bi komuni stranka koja je željela sastaviti kreditni trgovački ugovor otišla notaru da joj sastavi i zaključi ugovor. Notarska služba u Gradu bilježila je sve kreditne ugovore. Cijeli kreditni ugovor morao je biti upisan u notarsku knjigu. Taj se čin zvao rogatio. Notarska isprava činila je okosnicu financijskog života Grada. ${ }^{31}$

27 S. Marković, Baranke u Dubrovniku, 7 - 46; S. Marković, Stanovnišstvo, 306, 347 - 356, 360, 652, bilj. 1295.

28 HR-DAD, Testamenta Notariae, ser. 10, sv. 7, f. $96^{\prime}-98 \mathrm{v}$ (29. 8. 1385.).

29 Statut grada Dubrovnika: sastavljen godine 1272., priredili i preveli Ante Šoljić, Zdravko Šundrica i Ivo Veselić, Dubrovnik, 2002., (dalje: Statut grada Dubrovnika), 426 - 427; Gregor ČRemošNi K, Dubrovačka kancelarija do god. 1300. i najstarije knjige dubrovačke arhive, Glasnik Zemaljskog muzeja u Bosni i Hercegovini, sv. 39/2, Sarajevo, 1927., 231 - 233; Ignacij VoJe, Knjige zadolžnic: posebna notarska serija Dubrovniškega arhiva: univ. profesorju dr. Gregorju Čremošniku ob 10-letnici njegove smrti, Zgodovinski časopis, sv. XXII, br. 3 - 4, Ljubljana, 1968., 210 - 211.

30 Josip LuČIć, Pomorsko-trgovačke veze Dubrovnika s gradovima zetskog i dračkog primorja u XIII stoljeću, Pomorski zbornik, knj. 7, Zadar, 1969., 835.

31 O notarima i njihovoj službi vidjeti u: Branka Grbavac, Srednjovjekovni notarski formulari i njihovi sastavljači, Javni bilježnik, sv. 34, Zagreb, 2011., 33 - 38; Branka GrbavaC, Iz prošlosti javnog notarijata - od notarskog bastardela do izdane isprave, Javni bilježnik, sv. 36, Zagreb, 2012., $61-68$. 
Uz pomoć kredita trgovci su razvijali svoju trgovinu. Barski trgovci u Dubrovniku su, prije svega, željeli steći imetak i opstati. U analizi dokumenata o njihovoj kreditnoj trgovini komplicirano je odvojiti robu od novca, jer je većinom vrijednost robe izražavana u novcu. Vrijednost zajma trgovačke robe obračunavala se u dubrovačkim dinarima (grošima), perperima i mletačkim dukatima. U drugoj polovici XIV. stoljeća obračunska vrijednost dubrovačkog dinara iznosila je 30 folara. Jedan perper iznosio je 12 dinara, a dva perpera bila su ekvivalentna jednom mletačkom dukatu. Odnos mletačkog dukata prema dubrovačkom novcu iznosio je 24 dinara. Osamdesetih godina XIV. stoljeća taj je odnos promijenjen, pa je jedan dukat vrijedio 2,5 perpera ili 30 dinara. ${ }^{32}$ Komuna Bar je, primjerice, u ožujku 1395. od rizničara Dubrovnika uzela pozajmicu u iznosu od 450 dukata prema kursu 30 groša dubrovačkih kovanica po dukatu. ${ }^{33}$ Do kraja XIV. stoljeća tečaj je obično bio 30 dinara za jedan dukat. ${ }^{34}$

Trgovačka profesija zahtijevala je pokretljivost i česta putovanja. Vrijedan i vješt trgovac mogao je znatno popraviti svoju financijsku situaciju. ${ }^{35} \mathrm{Zbog}$ izuzetno povoljne gospodarske klime spretni barski trgovci ostajali su privremeno u Gradu nakon sklopljenog posla i obavljene robne razmjene. $U$ velikom postotku obrađenih kreditnih transakcija poslovalo se robom, a u manjem broju novcem. Zajam se u ovom periodu davao kratkoročno, na jedan do tri mjeseca (od prvog putovanja), rjeđe na pola ili godinu dana. Najčešće se u ugovorima određivao termin plaćanja u roku od tri mjeseca. Benedikt Kotrulj (Cotrugli), hrvatski trgovac i ekonomski pisac, ističe da kod prodaje robe na vremenski rok treba paziti na šest stvari: na robu koju prodaješ; osoba kojoj daješ mora biti poznata u trgovačkim krugovima i od povjerenja; rok mora biti što je moguće kraći; paziti na količinu dane robe i promatrati mogućnost njezina prometa; cijena treba biti pravedna i poštena da bi zarada bila za kreditora i dužnika; valja sastaviti jasnu javnu ispravu o dogovorenom poslu koju će notar upisati u svoj protokol. ${ }^{36}$

Kreditni su dužnici novac dobivali na osnovu garancija jamca, davanja zaloga i jamstva prokuratora. Jamac je garantirao svojom imovinom da će dužnik,

32 Vidjeti više u: Milan ReŠETAR, Dubrovačka numizmatika, I (historički) dio, Beograd, 1924., 50 - 59, 472 - 485; Milan RešETAR, Dubrovačka numizmatika, II (Opisni) dio, Beograd, 1925., 48 111; Irmgard MANKen, Dubrovački patricijat u XIV veku, I, Beograd, 1960., 106.

33 HR-DAD, Deb. Not., sv. 11, f. $123^{\prime}$ v (16.3. 1395.).

34 Vuk Vinaver, Prilozi istoriji plemenitih metala, cena i nadnica (srednjovekovni Dubrovnik), Istoriski glasnik, sv. 1 - 2, Beograd, 1960., 76.

35 Benedikt KotrulJ, Libro del arte dela mercatura. Knjiga o vještini trgovanja, priredila i prevela Zdenka Janeković Römer, Zagreb - Dubrovnik, 2009., 362 - 366.

36 B. Kot RULJ, Libro del arte, 367. 
do dana dospijeća, ispuniti svoju kreditnu obvezu. ${ }^{37}$ Ako dužnik vrati svoju kreditnu obvezu, jamac je oslobođen. No dokle god nije podmiren dug, kreditor je potraživao dugove od jamca. Najveći je broj Barana, zahvaljujući stalnim poslovnim vezama u Gradu, dobivao kredite bez jamaca. Jamci se veoma rijetko spominju u dokumentima vezanima za zaduženja barskih trgovaca. ${ }^{38}$ Barski trgovci dobivali su kredit na temelju zaloga, koji je morao je odgovarati vrijednosti kredita. U ugovoru se nalazila klauzula po kojoj je povjeritelj trebao vratiti zalog kada dužnik podmiri dug. Ako se po isteku roka dug ne izmiri, ulog, tj. založene stvari prodavane su na javnom mjestu. ${ }^{39}$ Ovaj oblik kreditiranja predstavljao je garanciju vjerovniku i mnogo manji rizik negoli obični zajmovi. Pokuratori se u dokumentima spominju kao opunomoćeni zastupnici. Njihova uloga je da u ime trgovca podignu kredit, podmire dug, vode parnicu na sudu, jamče da će se zajam vratiti na vrijeme i sklapaju druge različite ugovore. ${ }^{40}$ Prokuratori su poznavali dužnike i surađivali s kreditorima, zbog toga je postojala „vjera“ u njih da će nastali dugovi biti vraćeni.

U svim ugovorima kamata je iznosila $20 \%$ i bila je formulirana de quinque in sex per annum (što znači da se na pozajmljenih 10 vraćalo 12 dinara). Kamata se nije unosila u ugovor o zajmu. Trgovac koji je davao dužniku robu na kredit uračunao bi svoju zaradu u ukupan iznos u nekoj od prethodno navedenih moneta. U Dubrovniku je bilo dozvoljeno uzimanje zatezne kamate u iznosu od $15 \%{ }^{41}$ U Piranu je kamata iznosila $20 \%$, dok je na udruženo pozajmljivanje (kolegancija) dosezala čak do $25 \%{ }^{42}$

Poslije prelaska Dubrovnika pod vrhovnu zaštitu ugarsko-hrvatskog kralja dolazi do intenzivnijeg razvitka pomorske trgovine. ${ }^{43}$ Tijekom 1358. godine broj kreditnih zaduženja Barana u Dubrovniku iznosio je 10, a ukupni novčani iznos 1.209,5 dukata. ${ }^{44}$ Povoljne političke okolnosti utječu naredne godine na povećanje iznosa novčanog zaduženja za 2.949 dukata (18 kredita). Godine 1360. imamo 12 zaduženja ( 925 dukata). Tijekom 1361. godine dolazi do sukoba Dubrovnika s Vojislavom Vojinovićem i Kotorom. Zbog ovog konflikta

37 Ignacij Voje, Poslovna uspešnost trgovcev v srednjeveškem Dubrovniku, Ljubljana, 2003, 58 - 63.

38 HR-DAD, Div. Canc., sv. 25, f. 19v (30. 10. 1381.); sv. 35, f. 122'v (4. 11. 1404.).

39 O tome: I. VoJe, Kreditna trgovina, 124 - 128; Jelena DANilović, Zaloga u starom dubrovačkom pravu, Anali Pravnog fakulteta u Beogradu, sv. 35, br. 6, Beograd, 1987., 635 - 662.

40 I. VoJE, Kreditna trgovina, 128 - 130.

41 I. VoJe, Kreditna trgovina, 169 - 177.

42 Janez Peršič, Družina florentinskih bankirjev Soldanieri in Piran, Kronika, 25/1, Ljubljana, 1977. , $12-13$.

43 Dušanka Dinić-Knežević, Dubrovnik i Ugarska u srednjem veku, Novi Sad, 1986., 214 - 215.

44 Perperi i groši preračunati su u dukate. 
sredinom 1361. podanicima srpskog cara Uroša bilo je zabranjeno dolaziti u Grad i trgovati. Barska komuna bila je oslobođena od ovih dubrovačkih mjera. ${ }^{45}$ Od te godine komuna je priznavala vrhovnu vlast zetskih gospodara Balšića, koji su postali saveznici i dubrovački građani. Zbog nestabilnih političkih prilika u zaleđu broj kredita od 1362. do 1364. se smanjio. Također, trgovačku djelatnost u Gradu tih godina ugrozila je velika epidemija. ${ }^{46}$ Zbog poboljšanja političkih prilika narednih godina dolazi do povećanja trgovačke aktivnosti Barana. Kreditni poslovi idu uzlaznom putanjom 1364. (1.570 dukata), 1365. (2.186 dukata) i 1366. (2.717 dukata). Prosječan broj kredita bio je 12. Novčani iznos zajmova pada 1367. na $1.508,5$ dukata (18 kredita), a 1368 . na $1.381,5$ dukata (19 kredita). U usporedbi s prethodnim godinama, broj novčanih kredita povećao se, a iznos zaduženja smanjio. Vjerujemo da su to bili manji poslovi. Broj barskih trgovaca u Gradu tada se povećao. Najveći uspon kreditna trgovina dostiže 1369. godine. Ukupan broj kreditnih ugovora bio je 17, a zajam za trgovinu iznosio je 3.761,5 dukata (Grafikon 1). Povećanje obujma zajma ukazuje na razvojni porast njihove trgovine. Unaprjeđenju razvoja kreditne trgovine pridonijela je povelja braće Stracimira, Đurađa I. i Balše II. izdana Gradu sv. Vlaha 17. siječnja 1368. na rijeci Mati. Tom su poveljom Balšići Dubrovčanima ukinuli carinu na Danju i jamčili im slobodu kretanja na svom teritoriju bez plaćanja carina i drugih smetnji. ${ }^{47}$ Razvitak kreditne trgovine ne možemo pratiti za razdoblje od 1370. do 1378. jer notarske knjige nisu sačuvane. Tijekom 1380. sklopljen je samo jedan kreditni ugovor u vrijednosti od 70 dukata. Uzrok rjeđe poslovne suradnje je rat između Venecije i Genove (1378. 1381.). ${ }^{48}$ Tijekom 1381. godine upisana su dva zaduženja (140 dukata) Barana, a dan je i jedan kredit (120 dukata). Sljedeće godine uzeli su dva zajma u iznosu od 314 dukata, a dali su kao vjerovnici 12 kredita na zajam. To se može vidjeti iz raščlambe davanja kredita Baranima u Gradu (v. Grafikon 2). Tih je godina uspon u trgovačkoj karijeri imao Džive Alexevich, spominje se u notarijatu kao najveći kreditor iz Bara. U pitanju su solidni krediti, a ukupan iznos bio je 1.518 dukata. U 1383. imamo upisano samo jedno kreditno zaduženje (65 dukata) i dva kredita koja dao Džive (210 dukata). Zatim nastaje prekid u vrelima notarijata, nemamo pregled o kretanju zajmovne trgovine do 1389. godine. Od 1389. do 1395. primjećujemo kolebanja u opsegu kreditne trgovine. Na to

45 Monumenta Ragusina: libri reformationum III, A. 1359. - 1364., Zagrabiae, 1895., 92.

46 Nenad Vekarić, Vlastela grada Dubrovnika 1. Korijeni, struktura i razvoj dubrovačkog plemstva, Zagreb - Dubrovnik, 2012., 234.

47 Srđan Rudić, Povelja Balšića Dubrovčanima, Stari srpski arhiv, sv. 9, Beograd, 2010., 93 - 98.

48 Vinko Foretić, Povijest Dubrovnika do 1808. Dio 1, Od osnutka do 1526., Zagreb, 1980., 160 - 162. 
je utjecala kuga 1391. godine. Malo vijeće 1. travnja 1391. donosi odluku da se zbog kuge ne dozvoli vlasnicima brodova i njihovoj posadi, kao ni nikom drugom, odlazak u mjesta od Budve do Ulcinja (između njih se nalazi Bar). ${ }^{49}$ To znači da je i Baranima bio zabranjen dolazak u Grad. Tih godina u pitanju su manja zaduženja i broj kredita. Tijekom 1396. nije upisan ni jedan kreditni ugovor, a iduće godine samo jedno zaduženje (25 dukata). Kao uzrok stagnacije kreditne trgovine možemo navesti povećanu aktivnost Osmanlija u Zetskom primorju i sukob gospodara Đurađa II. i Grada oko naplate carina (1396. 1398.). Vjerojatno je to utjecalo da od 1398. do 1401. nema registriranih Barana u notarskim knjigama. U razdoblju od 1401. do 1405. nastavljen je trend smanjivanja intenziteta i vrijednosti kreditne trgovine. Taj trend opadanja kreditne trgovine bio je inače smanjen u Gradu zbog rata s bosanskim kraljem Ostojom i opasnosti od napada Ladislava Napuljskog. ${ }^{50}$

\section{GOSPODARSKE MOGUĆNOSTI I OBLICI POSLOVANJA BARSKIH TRGOVCA U GRADU SV. VLAHA - OBITELJ, POZNANSTVA I POSLOVNE VEZE}

Dubrovačka komuna bila je otvorena za sposobne i uspješne trgovce. U gospodarski život Grada bio je uključen veći broj Barana. Raščlambom arhivske građe sagledali smo kreditnu trgovinu barskih trgovaca, poglavito onih koji su u Gradu bili trajno nastanjeni, ali i onih koji su tamo boravili privremeno.

Džive Alexevich bio je barski trgovac velikog formata o čemu svjedoče arhivska vrela, u kojima se o njemu nalaze opsežni podatci. Zanimljivo je da nije bio predmetom zanimanja povjesničara. Njegov put trgovačke afirmacije moguće je pratiti od 1358. godine. Kada govorimo o njegovim početnim kreditnim poslovima, od 1358. do 1362., potrebno je naglasiti da je bio slabije „poznat" u trgovačkim krugovima. U osam kreditnih ugovora iznos zaduženja na temelju podataka iznosio je $1.171,5$ zlatnih dukata. ${ }^{51}$ Džive ubrzo svojom sposobnošću i prilagodljivošću postaje poznati trgovac kod dubrovačke vlastele i započinje njihova suradnja i njegov uspon. To se ogleda u činjenici

49 Nella LonZA, Zdravko ŠUndricA, Odluke dubrovačkih vijeća 1390 - 1392, Zagreb - Dubrovnik, 2005.,153; Zlata Blažına Tomić, Kacamorti i kuga: utemeljenje i razvoj zdravstvene službe u Dubrovniku, Zagreb - Dubrovnik, 2007., 87.

50 I. Voje, Kreditna trgovina, $228-230$.

51 Give Alexii de Antibaro... HR-DAD, Deb. Not., sv. 4, f. 33'v (16.7. 1358.); sv. 4, f. 33'v (24. 7. 1358.); sv. 4, f. $34 v$ (24. 7. 1358.); sv. 4, f. 68'v (1. 6. 1359.); sv. 5, f. 35v (21. 9. 1361.); sv. 5, f. 6'v (16. 2. 1361.); sv. 5, f. $46^{\prime}$ v (27. 4 1362.); sv. 5, f. $47 \mathrm{v}$ (29. 4. 1362.). 
da on postaje i vjerovnik. ${ }^{52}$ Kreditni ugovori otkrivaju širok krug ljudi s kojima je Džive poslovno surađivao, među kojima nalazimo ugledne dubrovačke

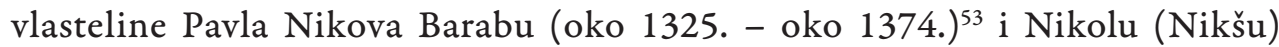
Nikiforova Gundulu (oko 1345. - 1411.). ${ }^{54} \mathrm{U}$ tri kreditna ugovora od 1366. 1369. zadužio se u iznosu od 552 dukata i 10 groša. ${ }^{55}$ Kao što smo spomenuli, kao i svi veliki trgovci, istodobno je davao kredite. Tijekom osamdesetih godina Alexevich je bio $u$ potpunosti afirmiran i uspješan u gospodarstvu Grada. Spominje se kao vjerovnik u 16 zadužnica, u vremenskom razdoblju od 1381. do 1399. godine. ${ }^{56}$ Kao vjerovnik posudio je 1.237 dukata, $1.743,5$ perpera i 9,5 groša. Radilo se o svotama od 35 do 390 dukata ili od 110 do 340 perpera. Dugogodišnjim poslovanjem Džive Alexevich stekao je velik društveni ugled i uspjeh u trgovačkom poslu. Imao je dućan u Gradu sv. Vlaha duži niz godina. Iz ugovora od 24. kolovoza 1398. saznajemo da je sklopio ugovor s trgovcem Živkom Rugichem zbog ustupanja dućana, koji je bio iznajmljen od dubrovačke komune. ${ }^{57}$ Džive je bio imućan čovjek, o čemu nam govori obrt novca, a nekretninu je sigurno posjedovao u Gradu. Imao je također i posjed u Župi. ${ }^{58}$ Posljednji put u vrelima spominje se početkom rujna 1398. godine. ${ }^{59}$ Nemamo podataka o njegovoj obitelji, kako se zvala njegova supruga i je li imao djecu. ${ }^{60}$ Bio je izuzetno sposoban i uspješan trgovac, a to nam pokazuju njegova aktivnost, poslovna umreženost, stalan promet i obrt novca.

$52 \quad$ HR-DAD, Deb. Not., sv. 7, f. 40v (5. 5. 1366.).

53 HR-DAD, Deb. Not., sv. 7, f. 38v (2. 5. 1366.); sv. 7, f. 81v (22. 3. 1367.); sv. 7, f. $143 \mathrm{v}$ (16. 5. 1368.); sv. 7, f. $185 v$ (14. 5. 1369.); Nenad VeKARIĆ, Vlastela grada Dubrovnika 7. Genealogije (A - L), Zagreb - Dubrovnik, 2016., 299.

54 HR-DAD, Deb. Not., sv. 9, f. 53v (18.3. 1381.). N. VEkARIĆ, Vlastela 7, 366.

55 HR-DAD, Deb. Not., sv. 7, f. 73v (21. 12. 1366.); sv. 7, f. 132v (25. 2. 1368.); sv. 7, f. $175^{\prime}$ v (25. 2. 1369.).

56 HR-DAD, Deb. Not., sv. 9, f. 53v (18.3. 1381.); sv. 9, f. $107^{\prime}$ v (24. 2. 1382.); sv. 9, f. 115v (9. 4. 1382.); sv. 9, f. $120^{\prime}$ v (30.4. 1382.); sv. 9, f. $137^{\prime}$ v (7. 5. 1382.); sv. 9, f. $144 v$ (16. 9. 1382.); sv. 9, f. $144^{\prime} v(17$. 9. 1382.); sv. 9, f. $145^{\prime}$ v (18. 9. 1382.); sv. 9, f. 179v (10.4. 1383.); sv. 9, f. $184 \mathrm{v}$ (10. 5. 1383.); sv. 10, f. 109 v (4. 5. 1391.); sv. 10, f. 120 v (19.6. 1391.); sv. 11, f. $16^{\prime}$ v (15. 4. 1391.); sv. 11, f. 150 'v (2. 8 . 1395.).

57 HR-DAD, Div. Canc., sv. 32, f. 173' (24. 8. 1398.). U dubrovačkim knjigama nekretnina 1419., 1424. i 1434. godine spominju se dućani koje je Rugich unajmio na dražbi od dubrovačke općine. Irena Benyovs ky Latin, Danko Zelić, Knjige nekretnina dubrovačke općine (13-18.st.), Vol. 1, Zagreb Dubrovnik, 2007., 190, 222.

58 HR-DAD, Div. Canc., sv. 29, f. $14 \mathrm{v}$ (29. 9. 1389.).

59 HR-DAD, Div. Canc., sv. 32, f. $177^{\prime}$ v (2. i 3. 9. 1398.).

60 U vrelima smo naišli na Druškusa Lesevicha kao jednog od poslanika Đurđa I. Balšića prilikom primanja svetodmitarskog dohotka u iznosu od 2.000 perpera. Deb. Not., sv. 8, f. 101v, (11. 11. 1377.). Nismo uspjeli uspostaviti srodstvo između Dživa i Druškusa. 
Kao rođak Dživa Alexevicha spominje se trgovac Đorđe Grilla de Antibaro. On najčešće uzima kredite u partnerstvu sa svojim sugrađanima iz Bara. On i Nikola Radovanich 23. svibnja 1366. godine zajedno uzimaju zaduženje kod Bogdanča Toloe u iznosu od 94 dukata. U zadužnici se ističe da je Đorđe bio rođak trgovca Džive, koji je već bio poznat u trgovačkim krugovima i vjerojatno jamčio za njega kod kreditora. ${ }^{61} \mathrm{U}$ prvoj polovici rujna 1366. posudio je s Mikom (Miho) Radovanichem iz Bara 175 dukata od istog vjerovnika. ${ }^{62} \mathrm{U}$ predviđenom razdoblju od tri mjeseca otplatili su prvi zajam i stekli povjerenje kod vjerovnika, a zatim uzeli dvostruko veće zaduženje. To su bila sredstva za novo trgovačko poslovanje, ali nije precizirano kojom su robom trgovali. $U$ rujnu iste godine Đorđe je s Mikom Radovanovim posudio od Martinuša Andrijina Sorga (oko 1370. - oko 1372.) 40 dukata. U ugovoru se ponovo spominje da je Đorđe Dživov rođak. ${ }^{63}$ Đorđe je bio trgovac skromnih trgovačkih sposobnosti.

Među Baranima u Dubrovniku koji su uzimali zajmove nalazimo Tripa Radimira. Tijekom 1358. i 1359. Tripo je sklopio četiri kreditna ugovora, a ukupan iznos bio im je 207 dukata. ${ }^{64}$ Nakon toga nastupa šutnja u vrelima. Iz dokumenata saznajemo da je imao dva sina, Sima i Dumka (Domo), ${ }^{65}$ koji su nastavili sitne trgovačke poslove. Međutim, moramo iznijeti rezervu da su Simichus i Dumcho ista osoba. U Debita se spominju u dva ugovora tijekom 1382. godine. Krajem travnja Simo je u partnerstvu s Radoslavom Bratoslavichem uzeo posudbu od 200 perpera kod Palka Nikolina Suesda. ${ }^{66}$ Simo i Palko surađivali su i ranije. Tjedan dana kasnije (2. svibnja 1382.) u notarijatu Palko Suesda izjavljuje da je od Dumka primio polovicu od 214 dukata, na temelju dužničke isprave od 6. travnja 1382. godine. Potvrda je poništena i proglašena nevažećom. ${ }^{67}$ Dumko je krajem prosinca 1397. primljen za dubrovačkog građanina. ${ }^{68} \mathrm{U}$ siječnju 1404. Dumko se oženio Marušom, kćeri Stanja Nesnovicha iz Dubrovnika. ${ }^{69}$

61 Nicola Radovanich de Antibaro et Georgius de Grilla, cognatus Give... HR-DAD, Deb. Not., sv. 7, f. 40v (23. 5. 1366.).

62 HR-DAD, Deb. Not., sv. 7, f. 59v (12. 9. 1366.).

63 HR-DAD, Deb. Not., sv. 7, f. 59v (15. 9. 1366.).

64 Trippe de Antibari... HR-DAD, Deb. Not., sv. 4, f. $32^{\prime \prime v}$ (5. 7. 1358.); sv. 4, f. 62v (1. 4. 1359.); sv. 4, f. $77^{\prime}$ v (9. 8. 1359.); sv. 4, f. 77'v (12.8.1359.).

65 Simichus, filius Trippe de Antibari... HR-DAD, Deb. Not., sv. 9, f. $118^{\prime}$ v (26. 4. 1382.); Dumcho, filio Trippe de Antibaro.... HR-DAD, Deb. Not., sv. 9, f. 121v (2. 5. 1382.).

66 HR-DAD, Deb. Not., sv. 9, f. $118^{\prime}$ v (26.4. 1382.).

67 HR-DAD, Deb. Not., sv. 9, f. 121v (2. 5. 1382.).

68 Dušanka Dinić-KNEŽEvić, Zetski primorski gradovi u svetlu dubrovačkih izvora, Srednjovjekovna istorija Crne Gore kao polje istraživanja, ur. Branislav Kovačević, Podgorica, 1999., 165.

69 D. Dinić-KnežEvić, Migracije, 205. 
Više članova barskog patricijskog roda Mauro spominje se da je u Knjizi zadužnica uzimalo zajam od Dubrovčana. ${ }^{70} \mathrm{U}$ vrelima se navodi da su Maroje i Nenac bili braća (sinovi Petrovi), ${ }^{71}$ a Domaša je vjerojatno bio Marojev sin. ${ }^{72}$ Članovi roda Mauro u ugovorima se zadužuju samostalno. Maroje se kao dužnik javlja u četiri ugovora (1358., 1361. i dva puta 1364.). ${ }^{73}$ Ukupan iznos njegova trogodišnjeg zaduživanja iznosio je 674 dukata. Nenac se spominje u kreditnim transakcijama tijekom 1359., 1360. (dva puta), 1362. i 1363. godine. Ukupan iznos zajma, na temelju podataka iz Debita, iznosio je 778 dukata, 312 perpera i 8 groša. ${ }^{74}$ Domaša se spominje da je u dva ugovora iz svibnja 1369 . od dubrovačkog vlastelina Pavla Barabe uzeo kredite u iznosu od 298 dukata. ${ }^{75}$ U notarijatu nema podataka o daljnjem kreditnom zaduživanju pripadnika barskog roda Mauro. Kada govorimo o njihovim kreditnim poslovima, potrebno je naglasiti poslovnu povezanost Maura i Barbara. Rod Barbara imao je intenzivne trgovačke odnose sa zetskim i albanskim primorjem. ${ }^{76}$ Njihov zajednički interes za novčanu dobit usmjerio ih je na trgovačku suradnju.

Marin (Maroje) Vidov Rigibat vjerojatno je aktivno sudjelovao u trgovačkom životu Grada i prije 1358. godine. Status dubrovačkog građanina stekao je 15. svibnja 1360. godine. ${ }^{77}$ Nekoliko mjeseci nakon toga Maroje se zadužio kod Nikole Rusinova Sarace (oko 1310. - 1363.) u iznosu od 42,5 perpera. ${ }^{78} \mathrm{U}$ vremenskom razdoblju od 1361. do 1364. godine spominje se da je uzeo četiri trgovačka kredita. Prvu posudbu uzeo je u lipnju 1361., u iznosu od 36 dukata. ${ }^{79}$ Dvije godine kasnije uzeo je dva kredita. Jedan kod Đura Vladimira (40 dukata), ${ }^{80}$ a drugi kod istaknutih dubrovačkih kreditora Đure Paskova Georgija (oko 1325. - oko 1363.) i Đure Jakovljeva Georgija (oko 1330. - oko 1374.) u vrijednosti

74 HR-DAD, Deb. Not., sv. 4, f. $75^{\prime}$ v (24. 7. 1359.); sv. 4, f. $126^{\prime}$ v (7. 11. 1360.); sv. 4, f. $126^{\prime}$ v (7. 9. 1360.); sv. 5, f. 62v (27. 10. 1362.); sv. 5, f. 89'v (13. 10. 1363.); Nenad VeKARIĆ, Vlastela grada Dubrovnika 2. Vlasteoski rodovi (A - L), Zagreb - Dubrovnik, 2012., 31; N. VEKARIĆ, Vlastela 7, 42; Nenad Vekarić, Vlastela grada Dubrovnika 8. Genealogije $(M-Z)$, Zagreb - Dubrovnik, 2017., 209.

75 HR-DAD, Deb. Not., sv. 7, f. $183^{\prime}$ v (3. 5. 1369.); sv. 7, f. $183^{\prime}$ v (9. 5. 1369.).

76 I. MANKen, Dubrovački, I, 123.

77 Maroe filius Vide de Rigitab de Antibaro... Monumenta Ragusina, III, 34.

78 HR-DAD, Deb. Not., sv. 4, f. 123'v (4. 8. 1360.); N. VEKARIĆ, Vlastela 8, 292.

79 HR-DAD, Deb. Not., sv. 5, f. 19'v (10.6.1361.).

80 HR-DAD, Deb. Not., sv. 5, f. 72v (24. 2. 1363.). 
274 dukata. ${ }^{81}$ Iznos drugog kredita ukazuje nam da je u pitanju bio neki solidniji trgovački posao. U vrelima nema spomena o njegovim kasnijim trgovačkim zaduživanjima.

U dubrovačkim vrelima često se spominje Đorđe iz Bara. Njegova trgovačka aktivnost može se pratiti od 1358. do 1371. godine. Đorđe je često kod Dubrovčana uzimao solidne iznose kredita, koje je na vrijeme vraćao. Većina dokumenata naglašava da je nećak Marinov, što je vjerojatno trebalo biti jamstvo za vjerovnike i druge poslovne partnere. ${ }^{82}$ Nismo uspjeli precizno identificirati koji je Marin u pitanju jer se nigdje ne navodi njegovo prezime. Možda je u pitanju Marin Rigibat, a moguće je da je tajnu trgovačkog zanata i uspjeha prenio na Đorđa. Tijekom 1358. godine zadužio se u iznosu od 191 dukata. ${ }^{83}$ Godine 1359 . bio je trgovački vrlo aktivan, zadužio se u šest kreditnih transakcija. Njegov ukupni dug te godine iznosio je 1.152 dukata. Iz notarijata se može vidjeti da je bio pojačano kreditno aktivan 1360. (531 dukat), 1361. (580 dukata), 1362. (150 dukata), 1363. (217 dukata i 7,5 groša), 1364. (584 dukata i 18 groša), 1365. (1.212 dukata i 95 perpera), 1366. (859 dukata), 1368. (55 dukata) i 1369. godine (549 dukata). ${ }^{84}$ Iznos zaduženosti ukazuje da je posudio velike svote novca, što indicira njegovu veliku trgovačku aktivnost. Iz jednog dokumenta (1361.) vidimo da je trgovao vinom..$^{85} \mathrm{Zbog}$ uspješnosti u poslovanju Đorđe je oko 1360 . godine postao dubrovačkim građaninom. ${ }^{86} \mathrm{Kao}$ dužnik najčešće se zaduživao u partnerstvu s rođakom Lazarom. ${ }^{87}$ Poslovno je surađivao $s$ dubrovačkim vlasteoskim rodom Georgio. Najčešće se zaduživao (8 kreditnih ugovora) kod Đure Georgija koji se bavio pomorskom trgovinom. Đuro je uglavnom trgovao svijećama i poljoprivrednim proizvodima. ${ }^{88}$ Vjerujemo da su neki od ovih artikala bili predmetom njihovih kreditnih ugovora. U ispravi od 4. lipnja 1371. spominje se da je Đorđe sklopio trgovačko partnerstvo s Dživom (Živko) Miletichem. ${ }^{89}$ Do umrežavanja je došlo zbog

81 HR-DAD, Deb. Not., sv. 5, f. 74v (8. 3. 1363.); N. VEKARIĆ, Vlastela 7, 300.

82 Nos quidem Georgius, nepos quondam Marini Antibarani... HR-DAD, Deb. Not., sv. 4, f. $35 \mathrm{v}$ (4. 8. 1358.).

83 HR-DAD, Deb. Not., sv. 4, f. 35v (4. 8. 1358.).

${ }^{84}$ HR-DAD, Deb. Not., sv. 4, f. 130v (1. 10. 1360.); sv. 5, f. 27v (9. 9. 1361.); sv. 5, f. 63'v (27. 10. 1362.); sv. 5, f. $74^{\prime}$ v (9. 3. 1363.); sv. 5, f. $104 v$ (9. 4. 1364.); sv. 5, f. $122^{\prime}$ v (15. 3. 1365.); sv. 5, f. $123^{\prime}$ v (22. 3. 1365.) (dva ugovora u istom danu); sv. 7, f. $60^{\prime}$ v (29. 9. 1366.); sv. 7, f. 61v (1. 10. 1366.); sv. 7, f. 161v (16. 10. 1368.); sv. 7, f. 170 'v (20.1.1369.).

85 Monumenta Ragusina, III, 65.

86 D. Dinić-KnežEvić, Zetski, 163.

87 Lazarus consanguineous domini Georgii... HR-DAD, Deb. Not., sv. 7, f. 60'v (29. 9. 1366.).

88 I. MANKen, Dubrovački I, 161; N. VEKARIĆ, Vlastela 7, 300.

89 HR-DAD, Div. Canc., sv. 23, f. $37^{\prime \prime}$ v (4. 6. 1371.). 
stvaranja profita i uvećanja kapitala. Đorđe je umro prije početka ožujka 1376. godine, što saznajemo iz kancelarijata..$^{90}$

Poznati vlastelinski i trgovački rod iz Bara bili su i Ruggi. Trgovac Marin Rugi spominje se u povijesnim vrelima 1332./1333. godine. ${ }^{91}$ Imao je brata Nadusa i sinove Siga, Andriju i Luku. Oni se spominju samo u nekoliko ugovora. Andrija je u ožujku 1361. posudio 14 dukata. ${ }^{92}$ Tijekom 1366. Sigo je podigao trgovački kredit u iznosu od 180 dukata. ${ }^{93}$ Nadus i Andrija su krajem travnja 1368. uzeli zajam od 105 dukata od kreditora Boganča Toloja. ${ }^{94}$ Luka Marinov posudio je 11. svibnja 1368. zajam od trgovca Luke Bune, ${ }^{95}$ koji je bio i Sigov kreditor. Dvadesetak godina kasnije Sigo se obvezuje da će vratiti kredit od 24 perpera i 4 groša Maru Bizanteu. ${ }^{96}$ Moguće da je Sigo bio u srodstvu s Perkom Ruggijem (Ruze) iz Bara. Perko se kao vjerovnik spominje u prosincu 1401. godine, tada je posudio Nikoli iz Bara 81 perper u kotorskim grošima. ${ }^{77} \mathrm{U}$ notarskim knjigama srednjovjekovnog Kotora 1 perper računao se kao 12 groša. Izračunali smo da bi u ovom slučaju to iznosilo 972 groša. ${ }^{98}$

U zadužnicama se na nekoliko mjesta spominje barska obitelj Petrovich. U vrelima se šezdesetih godina XIV. stoljeća spominju braća Nikola i Bogdan, ${ }^{99}$ a Ivan je vjerojatno bio $s$ njima $u$ nekom srodstvu. ${ }^{100}$ Nikola se sa svojom suprugom Gojislavom u svibnju 1364. zadužio u iznosu od 26 dukata kod Andrije (Andra) Jakovljeva Georgija (oko 1335. - prije 1372.). ${ }^{101}$ Živio je u Gradu s obitelji. Sljedeće godine dana 30. lipnja Nikola je u Malom vijeću primljen za dubrovačkog građanina. ${ }^{102}$ Krajem prosinca 1366 . u zadužnici se spominje da su on i njegov brat dugovali 67 dukata Boganču Toloju. ${ }^{103}$ Braća su nekoliko mjeseci kasnije nastavila trgovačku aktivnost. Njihova imena

\footnotetext{
90 HR-DAD, Div. Canc., sv. 34, f. 120v (6. 3. 1376.).

91 S. MARKović, Stanovništvo, 669.

92 HR-DAD, Deb. Not., sv. 5, f. 43v (9.3. 1361.).

93 Sigus, filius Marinci de Antibaro... HR-DAD, Deb. Not., sv. 7, f. 42v (22. 5. 1366.).

94 HR-DAD, Deb. Not., sv. 7, f. 141v (29. 4. 1368.).

95 Lucas Marini de Antibaro... HR-DAD, Deb. Not., sv. 7, f. 143v (11. 5. 1368.).

96 HR-DAD, Deb. Not., sv. 10, f. 36v (13. 12. 1389.).

97 HR-DAD, Deb. Not., sv. 12, f. $52^{\prime}$ v (11. 12. 1401.).

98 Jovan J. Martinović, Socijalno - ekonomska struktura društva u Kotoru prve polovine XIV vijeka, Kotor, 2017., 339.

99 Nos quidem Nicola Petrovich et Bochdanus frater eius de Antibaro... HR-DAD, Deb. Not., sv. 7, f. 73'v (30. 12. 1366.).

100 Inanus Petrovich de Antibaro... HR-DAD, Deb. Not., sv. 7, f. 1v (1. 10. 1365.).

101 HR-DAD, Deb. Not., sv. 5, f. 102'v (11. 5. 1364.).

102 Mihailo J. Dinić, Iz Dubrovačkog arhiva, knj. 1, Beograd, 1957., 12; D. Dinić-KNEžEvić, Migracije, 203.

103 HR-DAD, Deb. Not., sv. 7, f. $73^{\prime}$ v (30. 12. 1366.).
} 
spominju se u dva ugovora 13. ožujka 1367. godine. ${ }^{104}$ Zaduženja su imala za cilj udruživanje sredstava za realizaciju nekog trgovačkog posla. Ivan Petrovich spominje se u nekoliko kreditnih ugovora. Kao habitator Ragusii zadužio se 1 . listopada 1362. godine u iznosu od 372 dukata. ${ }^{105} \mathrm{U}$ tri ugovora od 1364. do 1366. posudio je 1.178 dukata. Inače se u tim ugovorima zadužuje sam. Glavni vjerovnik u svim zaduženjima bio je Petar Orsev Zrieva (prije 1347. - 1371.), ${ }^{106}$ koji je imao razgranate trgovačke poslove i raspolagao znatnim kapitalom. ${ }^{107}$ Priroda njihove veze bila je poslovna i interesna. Dio svog trgovačkog kapitala Petar je davao Ivanu na zajam, očekujući da će ga uvećati zajedničkim poslovanjem. Nije nam poznato kojom su robom trgovali. Krajem XIV. stoljeća u dokumentima se spominje Cnus Petrovich, vjerojatno sin Ivanov. On je imao dućan u Gradu i bavio se prodajom ulja. Tako je u jesen 1397. godine, u dva navrata, prodavao ulje za Mata Vidova Georgija (oko 1329. - 1400.). ${ }^{108}$

Članovi barskog patricijskog roda Samuelis također su sudjelovali u kreditnoj trgovini Grada. Ovo je jedan od najutjecajnijih barskih rodova. ${ }^{109} \mathrm{U}$ dubrovačkim vrelima spominju se sinovi Samuelisa Laurencija: Petar i Ivan. ${ }^{110}$ U dokumentima se spominje da je Ivan imao sinove Lovra i Ivana. ${ }^{111}$ Petar je bio prisutan u poslovnom okruženju Dubrovnika 20. veljače 1358. Tada se spominje da je posudio 28 dukata. ${ }^{112}$ Tijekom 1365. godine sklopio je dva kreditna ugovora ukupnog iznosa 275 dukata. ${ }^{113} \mathrm{U}$ drugoj polovici lipnja 1368. Petar je od Pavla Nikova Barabe posudio je 38 dukata. ${ }^{114}$ Osam mjeseci kasnije nastavljena

104 HR-DAD, Deb. Not., sv. 7, f. 80 'v (13. 3. 1367.); sv. 7, f. 80 'v (13. 3. 1367.).

105 HR-DAD, Deb. Not., sv. 7, f. 1v (1. 10. 1362.).

106 I. MAnken, Dubrovački patricijat u XIV veku II: geneološke table, Beograd, 1960., LXXVIII/2 (Zrieva).

107 I. Manken, Dubrovački I, $462-463$.

108 Desanka Dinıć-Knežević, Trgovina uljem u Dubrovniku u XIV veku, Historijski zbornik, god. XIII. - XIV., Zagreb, 1970. - 1971., 297; Nenad VeKARIĆ, Vlastela grada Dubrovnika 5. Odabrane biografije $(E-P e)$, Zagreb - Dubrovnik, 2014., 14 - 15.

109 S. MAR Ković, U kriposti suetoga, 191 - 215; S. MAR Ković, Stanovništvo, 673 - 678.

110 Petrus Laurencii Samueli de Antibaro... HR-DAD, Deb. Not., sv. 5, f. 122v, (7. 3. 1365.); Iohannes Laurencii Samuelis de Antibaro... HR-DAD, Deb. Not., sv. 4, f. 59'v (3. 3. 1359.); S. Marković, U kriposti suetoga, $194-195$.

111 Ego quidem Lauro, filius Iohannis de Samuelo de Antibaro... HR-DAD, Deb. Not., sv. 9, f. 219v (25. 8. 1383.). Ivan se spominje u vrelima 1428. godine kao gradski sudac u Baru. S. MAR Ković, U kriposti suetoga, $194-195$.

112 HR-DAD, Deb. Not., sv. 4, f. 21v (20. 2. 1358.).

113 HR-DAD, Deb. Not., sv. 5, f. 122v (7. 3. 1365.); sv. 5, f. $136^{\prime}$ v (20. 8. 1365.). U kancelarijatu je 25. srpnja 1382. zapisano da nije podmirio jedno svoje zaduženje iz 1365. godine. HR-DAD, Div. Canc., sv. 25, f. $124^{\prime} \mathrm{v}$ (25. 7. 1382.).

114 HR-DAD, Deb. Not., sv. 7, f. $147^{\prime} \mathrm{v}$ (21. 6. 1368.). 
je kreditna i trgovačka djelatnost s uglednim dubrovačkim vlastelinskim rodom Baraba. Tijekom 1369.i 1371. Samuel je od Pavla posudio 658 dukata. ${ }^{115}$ Nemamo podataka $s$ kojom je robom Petar tada trgovao. Iz drugih izvora znamo da se trgovina Pavla Barabe odnosila na željezo, olovo, kožu i drvo itd. ${ }^{116}$ Vjerujemo da su neki od ovih proizvoda bili predmetom njihovih kreditnih ugovora.

Drugi istaknutiji član roda Samuelis u kreditnoj trgovini Grada bio je Ivan. Krajem srpnja 1358. od vjerovnika Marina Sorga posudio je 140 dukata. ${ }^{117}$ Tijekom 1359. upisan je u jednoj zadužnici s prilično velikom svotom od 300 dukata. ${ }^{118}$ Nakon toga slijedi njegova intenzivna trgovačka aktivnost. Njegovi krediti poznati su nam od 1360. do 1366., naime šest godina uzastopce. U ovom kratkom vremenskom razdoblju uzimao je kredite najčešće kod sljedećih kreditora: Nikole Džorina Palmote, Andrije Lovrice Sorga (oko 1335. - 1413.) ${ }^{119}$ i Boganča Toloja. U osam ugovora od 1360. do 1366. posudio je $1.423,5$ dukata. ${ }^{120}$ Iz zaduženosti možemo vidjeti da je opseg poslovanja ovog trgovca dosegao solidne razmjere. Početkom prosinca 1365. posuđivao je tkanine od Vlaha Radovanova kao trgovačku robu. ${ }^{121}$ Osim tkaninama, trgovao je kožom i srebrnim predmetima. ${ }^{122}$ Nakon toga nastupa razdoblje tišine njegove trgovačkokreditne aktivnosti. Sljedeću generaciju ove obitelji nastavlja njegov sin Lovre, koji se u vrelima iz 1383. i 1395. spominje se kao prokurator, opunomoćeni trgovčev zastupnik. ${ }^{123} \mathrm{U}$ vrelima nismo pronašli podatke o daljnjoj kreditnoj aktivnosti roda Samuelis.

Osim vlasteoskog roda Goliebo u Dubrovniku, postojao je ogranak njihova roda u Baru. Od kraja šezdesetih godina XIV. stoljeća možemo pratiti trgovačku aktivnost ove barske obitelji. Predstavnik ovog ogranka bio je Niko Pankracijev (1325. - poslije 1368.). ${ }^{124}$ U vrelima se spominju dva sina Nika

115 HR-DAD, Deb. Not., sv. 7, f. 173v (4. 2. 1369.); Ludovicus de Thallóczy, Constantinus JirečEK, Emilianus de Sufflay, Acta et diplomata res Albaniae mediae aetatis illustrantia II (annos 1344 1406 continents), Vindobonae (Beč), 1918., 48.

116 I. MANKEN, Dubrovački I, 123.

117 HR-DAD, Deb. Not., sv. 4, f. $34^{\prime}$ v (27. 7. 1358.).

118 HR-DAD, Deb. Not., sv. 4, f. 59'v (3. 3. 1359.).

119 N. VEKARIĆ, Vlastela 2, 31; N. VEKARIĆ, Vlastela 8, 323.

120 HR-DAD, Deb. Not., sv. 4, f. 111 v (14. 5. 1360.); sv. 5, f. 10v (8. 3. 1361.); sv. 5, f. 46v (26. 4. 1362.); sv. 5, f. 69v (15. 1. 1363.); sv. 5, f. 69v (16. 1. 1363.); sv. 7, f. 19v (7. 12. 1365.); sv. 7, f. 70'v (1. 12. 1366.); L. Thallóczy, C. Jireček, E. Sufflay, Acta II, 48.

121 HR-DAD, Div. Canc., sv. 22, f. 90v (30.7. 1370.).

122 L. Thallóczy, C. Jireček, E. Sufflay, Acta II, 48; I. Manken, Dubrovački I, 418.

123 HR-DAD, Deb. Not., sv. 9, f. 219v (25. 8. 1383.); sv. 11, f. 152v (10. 8. 1395.).

124 HR-DAD, Deb. Not., sv. 7, f. $164 \mathrm{v}$ (30. 11. 1368.); N. VE KARIĆ, Vlastela 2, 273; N. VE KARIĆ, Vlastela 7, 335 . 
Golieba: Luka ${ }^{125}$ i Toma. ${ }^{126}$ Trgovac Luka spominje se u tri dokumenta. Iz isprave od 1. listopada 1368. doznajemo da je Pavle Baraba dao izjavu da mu je Luka Goliebo platio 41 dukat koji mu je dugovao na temelju zadužnice napisane 13. ožujka $1367 .{ }^{127}$ Krajem studenoga iste godine Luka je prema bilježničkom dokumentu izjavio da se njegov otac Niko obvezao u roku od šest mjeseci dati trećinu svojih nekretnina Bogdi Bochdanolu na račun miraza Mare (njegove kćeri), koja mu je postala supruga. U slučaju da Niko to ne učini za nekoliko mjeseci, Luka će zbog svoje sestre Bogdi isplatiti 300 dukata. ${ }^{128}$ Vjerojatno su barski Goliebi ispoštovali obvezu prema svom zetu, jer imamo šutnju u vrelima o tome. Sredinom travnja 1369. Luka je u partnerstvu s spomenutim Bogdanom Bogdanellom posudio 470 dukata od Marina Matova Georgija (oko 1342. 1388.). ${ }^{129}$ Devedesetih godina XIV. stoljeća zabilježena je trgovačka aktivnost Toma Nikova. Početkom ožujka 1393. Toma je u suradnji s Paluškom Ivana Bonde dobio posudbu od Tripa Đorđeva iz Kotora u iznosu 50 perpera i osam groša. Dužnici su dobili trgovačku robu (nije navedena vrsta), s rokom otplate od dva mjeseca. ${ }^{130}$ Iste godine, 10. rujna, Toma i Paluško ugovorili su novo poslovno udruženje, ${ }^{131}$ a njihova poslovna suradnja nastavljena je tri godine kasnije. Početkom lipnja 1397. posudili su robu u vrijednosti od 50 perpera i osam groša. ${ }^{132} \mathrm{U}$ navedenim ugovorima vjerovnik je bio Tripo pokojnog Đorđa iz Kotora. Braća Niko i Toma Goliebo u različito su se vrijeme bavili posredničkom trgovinom između Dubrovnika i Bara. Bili su manji trgovci, a u vrelima nemamo više podataka o njihovu financijskom i imovinskom stanju.

Među Baranima u Dubrovniku koji su uzimali zajmove nalazimo Andriju Simova Valentina. U trgovački život Grada uključio se sredinom šezdesetih godina XIV. stoljeća. U dva ugovora, iz 1366. (61 dukat) i 1367. (50 dukata), Andrija se kreditno zadužio kod Bogdaša Branote. ${ }^{133}$ Početkom veljače 1369. Valentino je uzeo trgovački zajam od Pavla Vidova Palmote (oko 1320. - 1370.)

125 Ego quidem Luchas, filius Nichi de Golebo de Antibaro... HR-DAD, Deb. Not., sv. 7, f. 164v (30. 11. 1368.). Ovaj podatak da je Niko imao još jednog sina Luku dopunjava impresivnu genealogiju N. VEKARIĆA, Vlastela 7, 335 (ogranak roda Goliebo u Baru).

126 Thome Nichi de Goliebo de Antibaro... HR-DAD, Deb. Not., sv. 9, f. 43v (3. 3. 1393.).

127 HR-DAD, Deb. Not., sv. 7, f. 123v (10. 1. 1368.).

128 HR-DAD, Deb. Not., sv. 7, f. $164 v$ (30. 11. 1368.). Podatak da je Niko osim Dobrule imao još jednu kćer Maru nadograđuje podatcima genealogiju N. VEKARIĆA, Vlastela 7, 335.

129 HR-DAD, Deb. Not., sv. 7, f. 182v (15. 4. 1369.); N. VEKARIĆ, Vlastela 7, 299.

130 HR-DAD, Deb. Not., sv. 9, f. 43v (3. 3. 1393.).

131 HR-DAD, Div. Canc., sv. 30, f. 59'v (10. 9, 1393.).

132 HR-DAD, Div. Canc., sv. 32, f. $52^{\prime}$ v (2. 6. 1397.).

133 HR-DAD, Deb. Not., sv. 7, f. 63v (15. 10. 1366.); sv. 7, f. 91v (12. 7. 1367.). 
u iznosu od 150 dukata. ${ }^{134}$ Iz kancelarijata doznajemo da Andrija potvrđuje da je 24. studenog 1369. dobio srebrni pojas od Grube Junijeva Mençea (oko 1325. 1371.) iz Dubrovnika i Vita Travaija iz Bara. ${ }^{135}$ Trgovao je uljem, koje je zauzimalo važno mjesto u prehrani dubrovačkog stanovništva. ${ }^{136} \mathrm{Na}$ temelju dugovanog iznosa mogla bi se izvući premisa da je bio osrednji trgovac.

Luka, pripadnik barskog patricijskog roda Maçman, bavio se trgovačkim poslom i uzimao je skromne kredite u Gradu sv. Vlaha. ${ }^{137}$ Prvi put se zadužio početkom lipnja 1366. u iznosu od 118 dukata. ${ }^{138}$ Početkom veljače 1369. posudio je 146 dukata od Luke Mihova Bone (oko 1325. - 1417.). ${ }^{139} \mathrm{Iz}$ ugovora od 26. ožujka doznajemo da je Luka posudio 19 dukata od obućara Bracana, sina Pavla Leucicha. Dug je trebao biti vraćen u roku od godinu dana. ${ }^{140}$ Tako dugi rokovi posudbe prilično su rijetki za barske trgovce. Navedeni dug povezan je sa sljedećim zajmom. Luka je istog dana upisan kao vjerovnik u javnobilježničkom uredu. Dao je zajam Jurku, sinu pokojnog Bracana iz Bara, u iznosu od 19 dukata. Rok za povratak kredita bio je tri mjeseca. Jurko je vjerojatno bio u skromnijoj financijskoj situaciji, pa je dodana klauzula da vjerovnik ima pravo prozvati ga na bilo kojem mjestu, sve dok iznos ne bude vraćen u cijelosti. ${ }^{141}$ Maçman je na taj način želio povećati svoj trgovački kapital za tri mjeseca, iz zajma koji mu je dao Bracan. A to je mogao učiniti još nekoliko puta, jer mu je to omogućilo razdoblje od godine dana. Luka je pripadao vlasteli zetskog gospodara Đurđa I. Balšića. Spominje se kao Balšićev poslanik u pismu dubrovačkim vlastima 22. studenog 1375. godine. ${ }^{142} \mathrm{U}$ studenom 1392. godine prodao je Maroju Lampridijevu Mençeu (oko 1335. - oko 1400.) masline iz Bara i primio je za to 10 perpera. ${ }^{143}$ Također, trgovao je vinom i uljem. ${ }^{144}$ Luka je bio solidan trgovac. Imao je osrednju razinu zaduženosti u poslovanju, a na to ukazuju trgovački poslovi.

134 HR-DAD, Deb. Not., sv. 7, f. 173v (1. 2. 1369.); N. VEKARIĆ, Vlastela 7, 42.

135 HR-DAD, Div. Canc., sv. 22, f. 17v (24. 11. 1369.); Nenad VeKARIć, Vlastela grada Dubrovnika 3. Vlasteoski rodovi $(M-Z)$, Zagreb - Dubrovnik, 2012., 49.

136 HR-DAD, Div. Canc., sv. 22, f. 18'v (28. 11. 1369.); D. Dinić-KnEŽEvić, Trgovina uljem, 290.

137 Luce Macimini de Antibaro... HR-DAD, Deb. Not., sv. 7, f. 179'v (24. 3. 1369.).

138 HR-DAD, Deb. Not., sv. 7, f. 43v (2. 6. 1366.).

139 HR-DAD, Deb. Not., sv. 7, f. $174 \mathrm{v}$ (7. 2. 1369.); N. VEKARIĆ, Vlastela 7, 107.

140 HR-DAD, Deb. Not., sv. 7, f. 179v (24. 3. 1369.).

141 HR-DAD, Deb. Not., sv. 7, f. 179v (24. 3. 1369.).

142 HR-DAD, Div. Canc., sv. 24, f. 89v, (22. 11. 1375.); Konstantin Ji REČE K, Spomenici srpski, Spomenik SKA, sv. 11, Beograd, 1892., 101, br. 20, 33; Tadija SMIČı LAs, Diplomatički zbornik Kraljevine Hrvatske, Dalmacije i Slavonije, sv. XV, Zagreb, 1934., 154 - 155, br. 116; Ljubomir Stojanović, Povelje i pisma I-1, Beograd, 1929., 107, № 108.

143 HR-DAD, Div. Canc., sv. 28, f. 42v (13. 11. 1392.); N. VekARIĆ, Vlastela 8, 44.

144 HR-DAD, Div. Canc., sv. 25, f. 4'v (30. 9. 1381.); L. Thallóczy, C. Jireček, E. Sufflay, Acta II, $61-62$. 
Barski rod Bacan (Bocan) pojavljuje se u dubrovačkim arhivskim vrelima. Dužnici iz ovog roda su Ivan i Marin, koji su vjerojatno bili bliska rodbina. ${ }^{145} \mathrm{Iz}$ vrela saznajemo da je Marin imao brata Dominika koji je bio svećenik. ${ }^{146} \mathrm{Krajem}$ pedesetih godina Ivan je počeo dolaziti u Grad. Iz notarijata se može vidjeti da je kreditno bio aktivan u godinama 1358., 1361., 1364., 1365. i 1366. ${ }^{147}$ Sam je uzimao kredite, a u pet kreditnih ugovora zadužio se u iznosu od 502 dukata. U prvoj polovici studenog 1377. Ivan je bio nuncij i prokurator Đurđa I. Balšića u Dubrovniku, zbog primanja svetodmitarskog dohotka u iznosu od 2.000 perpera. ${ }^{148}$ U siječnju 1367. Marin Bacan zaključio je s Pavlom Barabom ugovor o kreditu u ukupnom iznosu od 46,5 dukata. ${ }^{149}$ Nekoliko mjeseci kasnije, Marin je sklopio kreditni ugovor u partnerstvu sa Živkom Dobroevichem (de Pieclo). Tom prilikom zadužili su se u iznosu od 76 dukata. ${ }^{150} \mathrm{U}$ drugoj polovici 1368. uzeo je dva zaduženja u iznosu od 138 dukata. ${ }^{151}$ Vjerovnik svih tih dugova (260,5 dukata) bio je Pavle Baraba. Nakon spomenutih ugovora započinje razdoblje šutnje trgovačke i kreditne aktivnosti obitelji Bacana, iz nama nepoznatih razloga. U vrelima se 4. siječnja 1389. spominje Marinov brat, svećenik Dominik Bacan, koji je zajedno s rođakom Sergijem Rugiijem imao ovlast ugovoriti brak između Kate (kćeri Marina Bacana) i Petra Bobalija (sina pokojnog Vita). Osim miraza od 200 dukata, obitelj Bacan ima obvezu poslati nevjestu odjevenu i ukrašenu, kako i priliči barskim plemkinjama. ${ }^{152}$

Značajno mjesto u životu Bara tijekom XV. stoljeća zauzimao je rod Nati. ${ }^{153}$ Njegovi pripadnici se u drugoj polovici XIV. stoljeća slabo bilježe u dubrovačkim vrelima. Iz barskog roda Nati spominje se kao trgovac Maroje (Marin). ${ }^{154}$ Upisan je samo u dva dokumenta. U prvoj polovici siječnja boravio je u Dubrovniku,

145 Iohannes Bocani de Antibaro... HR-DAD, Deb. Not., sv. 4, f. 46'v (13. 10. 1358.); Marinus Bocani de Antibaro... HR-DAD, Deb. Not., sv. 7, f. 87v (29. 5. 1367.).

146 Presbyter Dominicus Baçan de Antibaro, frater Marini Baçan... HR-DAD, Div. Not., sv. 10, f. 36v (4. 1. 1389.).

147 HR-DAD, Deb. Not., sv. 4, f. 46'v (13. 10. 1358.); sv. 5, f. 35v (21. 11. 1361.); sv. 5, f. $113 \mathrm{v}(24.9$. 1364.); sv. 5, f. $136^{\prime}$ v (20. 8. 1365.); sv. 7, f. $70^{\prime}$ v (1. 12. 1366.).

148 HR-DAD, Deb. Not., sv. 8, f. 101v (11. 11. 1377.); Mihailo J. Dinić, Dubrovački tributi, Iz srpske istorije srednjeg veka, ur. Sima Ćirković, Vlastimir Đokić, Beograd, 2003., 733.

149 HR-DAD, Deb. Not., sv. 7, f. 77v (22. 1. 1367.).

150 HR-DAD, Deb. Not., sv. 7, f. 87v (29. 5. 1367.).

151 HR-DAD, Deb. Not., sv. 7, f. $124^{\prime}$ v (18. 1. 1368.).

152 HR-DAD, Div. Not., sv. 10, f. 36v (4. 1. 1389.); O tome opširnije u: Savo Marković, Jadranske trajektorije De Ruggiis, 8. Istarski biennale, Artisani et mercatores: o obrtnicima $i$ trgovcima na jadranskom prostoru, ur. Marija Mogorović Crljenko i Elena Uljančić, Poreč, 2019., 121 - 122.

153 S. MAR Ković, Stanovništvo, 651 - 652.

154 Maroe de Nati de Antibaro... HR-DAD, Deb. Not., sv. 7, f. 123v (14. 1. 1368.) 
a 14. siječnja 1368. zadužio kod Luke Bune u iznosu od 81 dukat. ${ }^{155}$ Isti se dan spominje u dokumentu o povratu duga Aleksija Cernoevicha i Miha Radovanova. Vjerovniku Pasku Matovu Mençeu (oko 1335. - prije 1383.) dugovali su 44 dukata i 8 groša. Maroje Nati je kao prokurator bio zadužen za daljnju naplatu duga. ${ }^{156}$ Maroje je imao kćer Marušu i sina Nikolu. ${ }^{157}$ Nikola je 1417. godine primljen za dubrovačkog građanina. Postao je vrlo uspješan i bogat trgovac. Bio je i rodonačelnik uglednog antuninskog roda Nalis. ${ }^{158}$

Vlasti barske komune uzimale su novac na posudbu od Grada sv. Vlaha i njegovih istaknutijih trgovaca. To su najčešće potrošački zajmovi, za izlazak iz financijskih problema. Bilo je raznih razloga za uzimanje kredita. Tako je barska komuna 10. srpnja 1369. preko svojih sudaca posudila 400 dukata od Pavla Barbare. U ugovoru se navodi da je zajam bio za „dobro“ Bara. Komuna je dužna otplatiti Gradu drugu polovicu duga do 8. kolovoza, i to u žitaricama. Obračun žita iznosio je 12 groša za svaki star dubrovačke mjere, a druga polovica trebala se platiti do sredine prosinca. ${ }^{159}$ Sredinom ožujka 1395. barska komuna uzela je zajam od dubrovačke općine u iznosu od 450 dukata. Grad Bar uzeo je ovaj zajam kako bi otkupio iz zatočeništva Barane koje je Đurađ II. Stracimirović tijekom opsade Bara zarobio i zatvorio. ${ }^{160}$

U kreditnoj trgovini Dubrovnika sudjelovali su i notari iz Bara. Bili su uključeni u trgovačke i gospodarske djelatnosti. Ivan Merula iz Napulja spominje se kao notar barske komune 1358. i $1368 .{ }^{161}$ On je u partnerstvu s Marinom Andrijinim Maracenijem iz Bara 24. travnja 1366. pozajmio od Živka Marculina 109 dukata. To nije bila obična posudba, već sa zalogom. Vjerovnik potvrđuje da je u zalog dobio srebro, tkanine i sklavonske groše. Dužnici će zalog dati za navedeni kredit. ${ }^{162}$ Vrijednost založenih predmeta odgovarala je vrijednosti zajma. Ovo je bio trgovački kredit u novcu, a ne u robi. Zalog je vraćen na vrijeme, a iz toga zaključujemo da je trgovački posao uspješno završen. Nema više spomena o kreditnoj i trgovačkoj aktivnosti barskog notara Ivana. Marin Moraceni nastavio je svoju kreditnu aktivnost, ali kao vjerovnik. Početkom ljeta 1367. zlatar Radoje (sin pokojnog Đorđa) i Beloje Stiepcovich uzajmili su od Marina 270 dukata. Rok

155 HR-DAD, Deb. Not., sv. 7, f. 123v (14. 1. 1368.).

156 HR-DAD, Deb. Not., sv. 7, f. 162v (3. 11. 1368.); N. VEKARIĆ, Vlastela 8, 2017., 48.

157 D. Dinić-Knežević, Migracije, 160.

158 Zrinka Pešorda-VArdić, U predvorju vlasti. Dubrovački antunini u kasnom srednjem vijeku, Zagreb - Dubrovnik, 2012., 85, 165, 170.

159 L. Thallóczy, C. Jireček, E. Sufflay, Acta $I I, 59-60$.

160 HR-DAD, Deb. Not., sv. 11, f. $123^{\prime}$ v (16. 3. 1395.).

161 S. MAR Ković, Notarijati, $834-835$.

162 HR-DAD, Deb. Not., sv. 7, f. 139v (23. 4. 1368.). 
otplate bio je godinu dana. Maraceni 2. kolovoza 1368. potvrđuje da je od Radoja na račun prve rate primio 30 dukata. ${ }^{163}$ Njihova suradnja nastavljena je odmah dva dana kasnije. Za novi trgovački pothvat Marin i zlatar Radoje posudili su 109 perpera i dva groša od Marina Georgija. ${ }^{164} \mathrm{Ne}$ znamo kojom su robom trgovali i nemamo podataka u arhivskoj građi o njihovu daljnjem poslovanju.

Barska obitelj Pasqualis (Pasko) u povijesnim vrelima spominje se devedesetih godina XIV. stoljeća. Članovi ove obitelji, Staniša, Miho i Niko, bili su bliska rodbina. Staniša se u dokumentima spominje kao stanovnik Dubrovnika. U ožujku 1395. podigao je tri zajma. ${ }^{165}$ Inače, u tim kreditnim ugovorima on se zadužuje sam. Ukupan iznos duga iznosio je 781 dukat i 24 groša. Dakle, 1395. godine na osnovu zaduženja zaključujemo da se njegova trgovačka djelatnost počela razvijati. Nažalost, u notarijatu o njemu nemamo više podataka. Miho i Niko nisu bili stanovnici Dubrovnika. U drugoj polovici siječnja 1392. Miho se zadužio u iznosu od 170 dukata. ${ }^{166}$ Krajem proljeća 1392. Niko je uzeo zajam od 163 dukata od Marina Matova Georgija (oko 1345. - 1417.). ${ }^{167} \mathrm{U}$ vrelima imamo tišinu o daljnjoj trgovačkoj aktivnosti pripadnika ove obitelji.

Stano (Stanoje) Hiliich porijeklom je bio Baranin koji je početkom osamdesetih godina stigao u Dubrovnik, a zatim se uputio u Prištinu. ${ }^{168} \mathrm{U}$ dubrovačkim dokumentima spominje se da je tijekom 1387. i 1388. trgovao većim količinama tkanina. ${ }^{169}$ Tkanine je nabavljao u Dubrovniku, a zatim ih preprodavao u Srbiji. Brz trgovački uspjeh utjecao je na to da je početkom travnja 1388., odlukom Malog vijeća izabran za dubrovačkog građanina. ${ }^{170}$ Uloga ovog trgovca prikazana je u istraživanju Ruže Ćuk. ${ }^{171}$ Iako je rodom bio iz Bara, Stano se u dokumentima o kreditnoj trgovini koje smo u ovom članku obradili spominje da je de Prestina. ${ }^{172}$ Prvih desetljeća XV. stoljeća trgovao je srebrom iz rudnika Srbije i na taj način uvećao dobit. Imao je razgranatu mrežu

163 HR-DAD, Deb. Not., sv. 7, f. 89'v (24. 6. 1367.).

164 HR-DAD, Deb. Not., sv. 7, f. $153^{\prime}$ v (4. 8. 1368.).

165 HR-DAD, Deb. Not., sv. 11, f. $124 \mathrm{v}$ (18. 3. 1395.); sv. 11, f. 124v (18. 3. 1395.); sv. 11, f. $125 \mathrm{v}$ (26. 3. 1395.).

166 HR-DAD, Deb. Not., sv. 10, f. $128^{\prime}$ v (21. 1. 1392.).

167 HR-DAD, Deb. Not., sv. 10, f. 149'v (12. 6. 1392.); N. VEKARIĆ, Vlastela 7, 299.

168 R. ĆuK, Porodica Stano, 17 - 25.

169 Dušanka Dinić-KnežEvić, Tkanine u privredi srednjovekovnog Dubrovnika, Beograd, 1982., 55, 68; R. ĆuK, Porodica Stano, 18.

170 Mihailo J. Dinić, Odluke veća Dubrovačke republike II, Beograd, 1964., 458.

171 R. ĆuK, Porodica Stano, $17-25$.

172 M. J. Dinić, OVDR II, 460; HR-DAD, Deb. Not., sv. 10, f. 95v (8. 1. 1391); sv. 10, f. 116'v (8. 6. 1391.); sv. 11, f. 16v (14. 4. 1393.); Vidjeti: Desanka KovačEvić-KoJıć, Priština u srednjem vijeku, Istoriski časopis, sv. 22, Beograd, 1975., 67. 
suradnika. ${ }^{173}$ Hiliich je posjedovao imanja u Baru, koja je zadržao dugo nakon preseljenja u Dubrovnik i Prištinu. Tijekom 1423. i 1438. prodao je svoju kuću u Baru, brojne posjede i maslinik. Postao je jedan od uglednijih dubrovačkih građana. Zbog svoje trgovačke imućnosti i uspješnosti ušao je u red Antunina prije 1430. godine. Trgovački je bio aktivan do polovice XV. stoljeća. ${ }^{174}$

Rod Zare bio je jedan od najznačajnijih u barskom patricijatu. Neki njegovi pripadnici preselili su se u Dubrovnik tijekom drugog desetljeća XIV. stoljeća. Najistaknutiji član dubrovačke obitelji Zare bio je Grube, kojemu je 1319. dodijeljeno dubrovačko građanstvo. Bio je uspješan trgovac i kreditor. Umro je 1357. godine. ${ }^{175} \mathrm{U}$ vrelima se kao pripadnici roda Zare spominju Marin i Petar, u drugoj polovici XIV. stoljeća. Marin vjerojatno nije bio Grubin sin, vjerojatno su bili u daljim obiteljskim odnosima, jer se ne spominje kao dubrovački građanin. ${ }^{176}$ S druge strane, Petar se spominje kao građanin Dubrovnika. ${ }^{177}$ Naslijedio je građansko pravo vjerojatno od svog oca Gruba. Marin je od Andrije Martolova Volçea (oko 1355. - 1429.) posudio 100 perpera početkom 1382., koje će otplatiti $\mathrm{u}$ roku do dva mjeseca. ${ }^{178}$ Petar se spominje u tri dokumenta u proljeće 1388. kao ovlašteni zastupnik (prokurator) trgovca Dominika Modrocura. ${ }^{179}$ Nemamo podatke o Petrovoj kreditnoj aktivnosti. Posljednji poznati član obitelji Zare u Gradu sv. Vlaha bio je don Andrija, barski i dubrovački kanonik. Andrija je vjerojatno bio Petrov sin. Spominje se 22. listopada 1404. kao jedan od zastupnika Domka Tripova iz Bara. ${ }^{180}$ Iz kasnijih vrela doznajemo da je posjedovao nekoliko nekretnina u Dubrovniku i Baru. ${ }^{181}$

Iz barske obitelji Viciano u Debita je registrirano nekoliko članova, koji se pojavljuju kao dubrovački dužnici. Ivan Vician spominje se kao dužnik 16. veljače 1361. godine. Tom prilikom uzeo je zajam u iznosu od 150 dukata. ${ }^{182}$ Krajem veljače 1367. Marin (Marko), sin Nata Viciana, posudio je od Luke Bune

173 R. ĆuK, Porodica Stano, 18 - 22.

174 R. Ćuk, Porodica Stano, 23 - 24; Z. PeŠorda-VArdić, U predvorju, 45, 90 - 91, 99 - 100, 140.

175 R. Ćuk, Dubrovačka porodica Žaretić, 53 - 55; S. Marković, Stanovništvo, 124, 128, 692 - 694.

176 Marinus de Zare de Antibaro... HR-DAD, Deb. Not., sv. 9, f. 100v (6. 1. 1382.).

177 HR-DAD, Div. Canc., sv. 27, f. 118v (11. 5. 1388.).

178 R. Ćuk napravila je pogrešku navodeći da je rok otplate od dvije godine. Ruža Ćuk, Dubrovačka porodica Žaretić, 55, nap. 16. Deb. Not., sv. 9, f. 100v (6. 1. 1382.). O kreditoru Andriji Volçou vidjeti više u: Nenad VeKarić, Vlastela grada Dubrovnika 6. Odabrane biografije (Pi - Z), Zagreb - Dubrovnik, 2015., 264 - 265.

179 L. Thallóczy, C. Jireček, E. Sufflay, Acta $I I, 100-101$.

180 HR-DAD, Deb. Not., sv. 12, f. 206v (22. 10. 1404.).

181 R. Ću K, Dubrovačka porodica Žaretić, 56, nap. 17; S. MAR Ković, Stanovništvo, 695.

182 HR-DAD, Deb. Not., sv. 5, f. 6'v, (16. 2. 1361.). 
39 dukata. ${ }^{183} \mathrm{U}$ prvoj polovici travnja 1369. Marin Stepov i Marin Viciano, u partnerstvu s Marinom Natovim iz Bara, posudili su 270 zlatnika od Martina Georgija. ${ }^{184}$ Nemamo spomena o daljnjoj kreditnoj trgovini članova ove obitelji.

Iz barske obitelji Modrocur (Modroculli) potiče Teodor Gaucelov. Ugovorom od 26. studenog 1360. posudio je od Nikole Palmote 130 dukata. Dvadeset pet godina kasnije $u$ ispravi se navodi da cijeli dug nije plaćen, tj. da je ostao dužan 90 dukata. Teodor se 18. prosinca 1385. obvezao Mari, supruzi pokojnog Nikole, i njegovim nasljednicima da će navedeni dug biti vraćen u ratama od 15 dukata godišnje, do pune isplate. ${ }^{185}$ Iako je postavljen novi dodatni rok za dužnika da bezuvjetno podmiri dug, to nije učinjeno. To saznajemo iz isprave od 5. srpnja 1394. godine. Mara je u međuvremenu umrla, pa je sastavljen novi ugovor, kako dug ne bi zastario. Modrocur se obvezao da će Nikolinim sinovima vratiti dug od 90 dukata s rokom naplate od devet godina (deset dukata godišnje). ${ }^{186}$

Marinče (Marin) Miroseuich iz Bara, nekadašnji vikar Đurđa II. Stracimirovića Balšića na Korčuli (1399. - 1400. i u razdoblju travanj - lipanj 1402. godine), spominje se kao dužnik. On je podigao zajam 2. svibnja 1404. od Marina Georgija u iznosu od 106 dukata. ${ }^{187} \mathrm{U}$ kancelarijatu 15. listopada 1402. spominje se da je Marin posudio 130 perpera. ${ }^{188}$

Iz analize strukture dužnika možemo ustvrditi da u ovom razdoblju najveće kredite podiže Džive Alexevich. On je podigao 13 kredita, a ukupni iznos zaduženja bilo je 2.222,5 dukata. Kao došljak postao je domicilan u Gradu (habitator). Trgovački napredak iskazao je kao vjerovnik, dao je 23 kredita na zajam (790 dukata, 3.091 perper i 18,5 groša). ${ }^{189}$ Kao stanovnici u Gradu upisani su članovi obitelj Petrovich, kojima je Grad postao drugi dom. Dubrovčani su prihvatili za cives Đorđa, Marina Vidova Rigibata te Stana Hiliicha, jer su bili vrlo uspješni i bogati trgovci, pa su kao takvi mogli biti od koristi dubrovačkim vlastima. Građanstvo je dobio i Dumko Radimiro. Dobivanjem građanstva

183 Ego quidem Marce, filius Nati Viciano de Antibaro... HR-DAD, Deb. Not., sv. 7, f. 80v (25. 2. 1367.).

184 Nos quidem Marinus quondam Stepe de Viciano, Marinus quondam Tome de Viciano... de Antibaro... HR-DAD, Deb. Not., sv. 7, f. 180v (8. 4. 1369.).

185 HR-DAD, Div. Canc., sv. 26, f. $11^{\prime}$ v (18. 12. 1385.).

186 HR-DAD, Deb. Not., sv. 11, f. 86'v (5. 7. 1394.).

187 HR-DAD, Deb. Not., sv. 12, f. 171v (2.5. 1404.).

188 HR-DAD, Div. Canc., sv. 34, f. 170v (15. 10. 1402.).

189 Usporedi: Z. Janeković-Römer ukazala je na primjeru trgovca Džore Gostigna i njegovu društvenom položaju (također među habitatores) da dubrovačko građansko pravo nije bilo nužno za uspjeh. Zdenka Janeković-Römer, Georgius Scambe de Gostigna, habitator Ragusii olim de Arbo, uspješan Dubrovčanin bez građanskoga prava, 8. Istarski biennale, Artisani et mercatores: 0 obrtnicima i trgovcima na jadranskom prostoru, ur. Marija Mogorović Crljenko i Elena Uljančić, Poreč, 2019., $9-22$. 
Barani su stekli jednaka prava kao i rođeni Dubrovčani. Barski notar Ivan Merula boravio je i posudio novac nekoliko puta u Gradu. Kao sitniji zajmodavci spominju se Đorđe Grilla, Nikola Radovanich i Marino Maraceni, vjerojatno zanatlije. Članovi iz barskih plemićkih rodova Mauro, Ruggi, Samuelis, Pasqualis, Valentino, Maçman, Goliebo, Bacan, Nati, Zare, Viciano, Modrocur i Miroseuich registrirani su Notarskim zadužnicama. Romanski element prevladava u prezimenima barske vlastele. Ovi trgovci plemići privremeno su boravili u Gradu zbog poslovnih aktivnosti. Upisani su u dokumentima kao stranci (forenses). Iz dokumenata vidimo da je ova kategorija stanovništva, pri čemu mislimo na barske plemiće, bila solidno umrežena u trgovački sustav Grada. ${ }^{190}$

\section{MANJE POZNATI TRGOVCI}

Izuzev utjecajnijih trgovačkih obitelji i trgovaca, u arhivskim se vrelima pojavljuju trgovci koji su jednom ili nekoliko puta uzeli kredit. Kao dužnici iz Bara krajem pedesetih godina XIV. stoljeća pojavljuju se Bolko Vidošev i Ivan Petrov. Njih dvojica upisala su se u dva zaduženja 21. i 22. siječnja 1359., koja su iznosila 807,5 dukata. ${ }^{191}$ Godinu dana kasnije Ivan se javlja kao dužnik i pozajmljuje 224 dukata i 20 groša. ${ }^{192}$ Šezdesetih godina XIV. stoljeća u Dubrovniku javlja se Petar Marmorius. ${ }^{193}$ Njegov otac Nikola potjecao je iz Bara. Nije nam poznato kada je Petar postao stanovnik Grada. Vjerojatno je bio obrtnik, bavio se trgovinom na malo i upisan je samo u nekoliko notarskih ugovora. Tijekom 1367. zadužio se u dva kreditna ugovora, a ukupni iznos zaduženosti iznosio je 110 dukata i 12 perpera. ${ }^{194} \mathrm{U}$ Knjizi zadužnica od 1358. do 1370. kredite su uzeli: Ivan (85 dukata), Andreas Miletin (80 dukata), Sredoje (19 dukata), Goce i Pavo (100 dukata), Maroje Vitov (42,5 perpera), Andrija i Alojz (37 dukata), Bratan Kapelez (64 dukata), Radoslav Budin (12 dukata), Marin Dragov (60 dukata), Prone (45 perpera), Pronoje i Nisa (100 dukata), Đuro Muscach (25 perpera),

190 Vidjeti više u: Jovanka MijušKović, Dodjeljivanje dubrovačkog građanstva u srednjem veku, Glas SANU, sv. 9, Beograd, 1961., 106 - 127; Tomislav RAUKAR, Cives, habitatores, forenses u srednjovjekovnim dalmatinskim gradovima, Historijski zbornik, sv. 29 - 30, Zagreb, 1976. 1977., 140 - 143; Zdenka JANEKOVIĆ-RÖMER, Građani, stanovnici, podanici, stranci, inovjerci u srednjovjekovnom Dubrovniku, Raukarov zbornik: zbornik u čast Tomislava Raukara, ur. Neven Budak, Zagreb, 2005., 321 - 323, 327 - 328; Z. PeŠORDA-VARDIĆ, U predvorju, 80 - 89.

191 HR-DAD, Deb. Not., sv. 4, f. $55^{\prime}$ v (21. 1. 1359.); HR-DAD, Deb. Not., sv. 4, f. $55^{\prime}$ v (22. 1. 1359.).

192 HR-DAD, Deb. Not., sv. 4, f. 122 'v (30. 7. 1360.)

193 Petrus Marmorius, filius quondam Nicolai de Antibaro, habitator Ragusii... HR-DAD, Deb. Not., sv. 7, f. 87v (9.6.1367.).

194 HR-DAD, Deb. Not., sv. 7, f. 87v (9. 6. 1367.); sv. 7, f. 158v (28. 9. 1368.). 
Vuk (8 dukata), Đorđe Maragi (170 dukata), Tomo Mihaelisov i Nikola Đorđev Balech (305 dukata), Ivan Musoevich (28 perpera), Gvarnerije (54 dukata), Jakov Laurencijev Branji (100 perpera) i Lovro Bragni (100 perpera). ${ }^{195}$

Tijekom 1360. godine trgovac Tvrdoje Stanijev Çioda spominje se u tri zadužnice. Njegovi kreditni dugovi iznosili su 403 dukata. ${ }^{196} \mathrm{Na}$ temelju dugovanog iznosa mogla bi se izvući premisa da je te godine njegov trgovački posao bio uspješan. Nažalost, u vrelima nemamo ostalih podataka o njemu da bismo mogli nešto više zaključiti. Vito Centinara, iz patricijskog barskog roda Zentivaglia, ${ }^{197}$ spominje se u dva kreditna ugovora. U suradnji s Ivanom Vitinim iz Svača, 1. veljače 1369. podigao je 442 dukata od vjerovnika Grube Mençea. ${ }^{198}$ Dvadeset četiri godine kasnije sastavljen je novi ugovor, koji nam daje informacije da je Vito tek tada vratio dugove. ${ }^{199}$

U nekoliko ugovora spominju se članovi obitelj Grubo, Mile i Pavle. Mile se spominje u dva ugovora, iz 1359. i 1364. godine. ${ }^{200} \mathrm{U}$ tri ugovora upisan je Pavle. Kredite je podizao tijekom 1359. (jedan ugovor) i 1360. (dva ugovora) u partnerstvu. Ukupan iznos zaduženosti bio je 286 dukata. ${ }^{201}$ Pavle je trgovao vinom. Bogdan Lucich (de Gravossio) je 4. veljače 1376. prodao je vino Pavlu. ${ }^{202}$ Iduće godine, 8. ožujka, nastavljena je poslovna suradnja. Lucich navodi da je Pavlu prodao sve vino koje će dati iz dva vinograda u Gružu. Vinograde je unajmio od Paska Matova Restija (oko 1350. - 1438.). Cijena vina je četiri groša po kvinći. Bogdan obećava da će za sebe zadržati samo četiri kvinće. Kao zalog za vino, od Pavla je dobio šest perpera. ${ }^{203}$ Mjesec dana kasnije saznajemo da je Pavle umro (30. ožujka 1377). ${ }^{204}$ Pavle je imao sina Ivana, koji se u vrelima spominje

195 HR-DAD, Deb. Not., sv. 4, f. 33v (9. 7. 1358.); sv. 4, f. 94v (6. 12. 1359.); sv. 4, f. 101v (7. 2. 1360.); sv. 4, f. $102^{\prime}$ v (27. 2. 1360.); sv. 4, f. $123^{\prime}$ v (4. 8. 1360.); sv. 5, f. 69'v (22. 1. 1363.); sv. 5, f. $82^{\prime}$ v (2. 6. 1363.); sv. 5, f. $96^{\prime}$ v (20. 2. 1364.); sv. 5, f. $104 \mathrm{v}$ (10.6. 1364.); sv. 5, f. $94^{\prime}$ v (19. 1. 1364.); sv. 5, f. $104^{\prime}$ v (13. 6. 1364.); sv. 7, f. $20^{\prime}$ v (18. 12. 1365.); sv. 7, f. $77^{\prime}$ v (5. 2. 1367.); sv. 7, f. 89'v (24. 6. 1367.); sv. 7, f. $91^{\prime \prime v}(16.7 .1367$.$) ; sv. 7, f. 92^{\prime}$ v (25. 7. 1367.); sv. 7, f. $93^{\prime \prime v}$ (23. 8. 1367.); sv. 7, f. $135^{\prime}$ v (10. 3. 1368.); sv. 7, f. $144^{\prime}$ v (21. 5. 1368.); sv. 7, f. $148 v$ (21. 6. 1368.); sv. 7, f. 203v (18. 6. 1369.).

196 HR-DAD, Deb. Not., sv. 4, f. $104 v$ (12. 3. 1360.); sv. 4, f. $128^{\prime}$ v (20. 9. 1360.); sv. 4, f. $129 v(26.9$. 1360.).

197 Da je Vito Centinara iz barskog patricijskog roda Zentivaglia skrenuo nam je pažnju dr. Savo Marković, na čemu mu najtoplije zahvaljujemo.

198 HR-DAD, Deb. Not., sv. 7, f. 172v (1.2. 1369.).

199 HR-DAD, Deb. Not., sv. 9, f. $218^{\prime}$ v (24. 8. 1383.).

200 HR-DAD, Deb. Not., sv. 4, f. $61^{\prime}$ v (21. 3. 1359.); sv. 5, f. 103v (27. 5. 1364.).

201 HR-DAD, Deb. Not., sv. 4, f. $72^{\prime}$ v (19. 6. 1359.); sv. 4, f. $104^{\prime}$ v (13. 3. 1360.); sv. 4, f. $136 \mathrm{v}$ (24. 11. 1360.).

202 HR-DAD, Div. Canc., sv. 24, f. $105^{\prime}$ v (4. 2. 1376.).

203 HR-DAD, Deb. Not., sv. 8, f. $18^{\prime}$ 'v (8. 3. 1377.).

204 HR-DAD, Deb. Not., sv. 8, f. 35v (30. 4. 1377.); N. VEKARIĆ, Vlastela 6, 127 - 128. 
kao svećenik i zavještalac. ${ }^{205} \mathrm{U}$ kancelarijatu je zabilježeno da je u kolovozu 1375. trgovao vinom. ${ }^{206} \mathrm{U}$ prvoj polovici travnja 1382. Petroje iz Dubrovačke župe primio je od Ivana 16 perpera. ${ }^{207}$ Nemamo podatka o njegovim kasnijim kreditnim transakcijama.

U vrelima se spominje Radovanov sin (iz Bara) Miho. U lipnju i srpnju 1367. Miho je podigao tri kreditna ugovora (106 dukata i 8 groša) u partnerstvu sa zlatarom Aleksejem. ${ }^{208}$ Ovo partnerstvo nije puno imalo uspjeha, jer se iduće godine spominje da Miho nije vratio dug od 23 dukata. ${ }^{209}$ Od 1380. do 1405. kredite su uzeli i sljedeći Barani: Ivan Kicarevich (70 dukata), Bokša Perovich (20 dukata), Tonko Nikolete Tani (139 dukata), Nikola Stanov (41 perper), Đuro Bubi (66 dukata) i Manče Teodorov (255 perpera). ${ }^{210}$

Iz fragmentarne analize zaduženja manje poznatih trgovaca uočavamo je najveći broj bio pučana. Kao nositelji obrtničkih zanimanja i pomorci, sudjelovali su u kreditnoj trgovini Grada. Zbroj svih zaduženja prikazuje ih kao male trgovce čija su novčana zaduženja skromnih razmjera. Naime, svi navedeni zajmovi od jednog ili nekoliko puta ukazuju da navedeni trgovci nisu uspjeli ostvariti veći uspjeh u trgovačkoj aktivnosti.

\section{TRGOVAČKA DRUŠTVA, ROBA I MOGUĆNOSTI ZARADE ZA BOGATE I SIROMAHE}

Barski trgovci usmjeravali su se prema onoj trgovačkoj robi koja je mogla jamčiti dobar uspjeh i profit. Da bi zadovoljile životne potrebe svojih stanovnika, gradske vlasti uzele su u svoju nadležnost opskrbu žitom. ${ }^{211}$ Barski trgovci uvozili su žito s albanskog primorja u Grad. Početkom svibnja 1398. Jure Ilijin iz Bara obvezao se dostaviti žito Gradu. ${ }^{212} \mathrm{U}$ svibnju 1399. Francesco

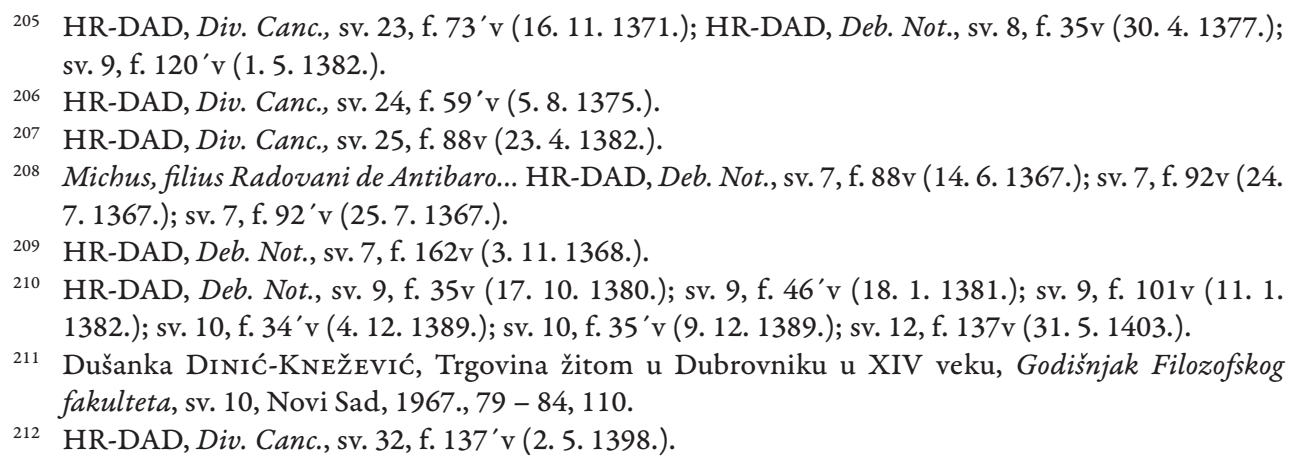


Povesario povjerio je vreću lana Petroju iz Bara, koji je živio u Dubrovniku, da ga proda uz zaradu od 2,5 dinara od centenara. ${ }^{213}$ Marinče Mirossio trgovao je žitom. Početkom rujna 1402. Gojač Milošev iz Skadra isporučio mu je žito u Bar. ${ }^{214}$ Vjerojatno je to isto žito preprodao dubrovačkom nosaču Miladinu. Nemamo podataka o količini žita, njegovoj cijeni i zarađenoj sumi novca. Menče Zane iz Bara spominje se da je 1403 . godine trgovao žitom. ${ }^{215} \mathrm{Nismo}$ uspjeli naći daljnje obavijesti o trgovini žitom.

U vrelima se spominje trgovina soli. U drugoj polovici ožujka 1371. Francescu Baldolliju trebalo je prenijeti sol u barsku luku. ${ }^{216} \mathrm{U}$ prosincu 1375. Nikola Bogojevich iz Lopuda obvezao se da će vino i sol prevoziti do barske luke. ${ }^{217}$ Sredinom studenog 1397. zabilježena je velika isporuka soli iz Dubrovnika u Bar. Antonije iz Ulcinja (nastanjen u Mletcima), mornar i patrun barke, prodao je Marinčetu iz Bara 80 vreća soli valonske mjere. On se obvezao da će sol dostaviti u Bar i ondje je istovariti te dostaviti Marinčetovu bratu Teodosiju. Marinče će mu zatim u roku od tri dana isplatiti cijenu soli - deset groša za svaki barski modij - i deset perpera za obavljenu plovidbu. ${ }^{218}$

Barski trgovci najčešće su u Dubrovnik uvozili ulje, koje je zauzimalo važno mjesto u ishrani dubrovačkog stanovništva. Krajem studenoga 1369. Andrija Valentino iz Bara prodao je Ivanu Ogrei 40 stari ulja, po cijeni od 10 groša za star. ${ }^{219}$ Vlah Radovanov bio je jedan od glavnih suradnika barskih trgovaca u nabavci ulja. On je krajem rujna 1381. od Luke Maçmena kupio 10 milijara ulja po cijeni od 30 dukata po milijaru, računajući 30 groša za jedan dukat. Polovica otplate trebala je biti sprovedena u novcu, a polovica u tkaninama. ${ }^{220} \mathrm{Cijenu}$ na malo od 80-ih godina XIV. stoljeća počele su određivati gradske vlasti, koje se od tog vremena sve više brinu za opskrbu Grada uljem. ${ }^{221}$ U siječnju 1397. u Grad je stiglo ulje Đurđa II. Balšića, a za njega je bio zadužen Mato Vidov Georgio. Sljedećeg mjeseca nekoliko je dubrovačkih trgovaca nabavljalo ulje u Baru, ali im je Đurađ II. naplatio veću carinu. Zbog toga su oni podnijeli tužbu protiv

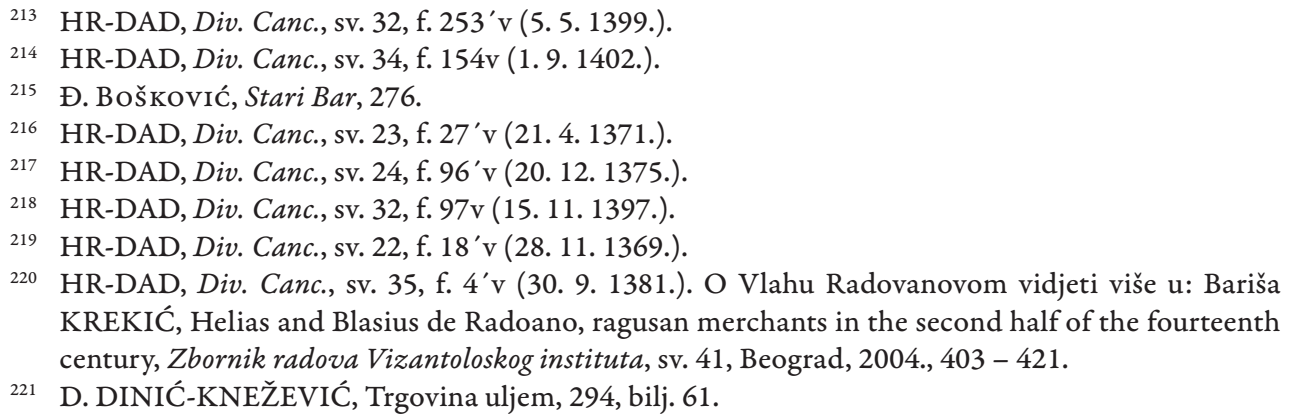


Mata, koji je bio zadužen za ulje iz Bara. ${ }^{222}$ Georgio je čak bio označen kao Balšićev čovjek. ${ }^{223}$ U drugoj polovici ožujka 1397. Vijeće umoljenih oslobodilo ga je optužbi, a Mato je oštećenima nadoknadio carinu dajući im odgovarajuću količinu Balšićeva ulja. Preostali dio mogao je izvoziti. U jesen 1398. Grad je imao poteškoća s nabavkom ulja. Cijena ulja porasla je tada s 20 na 25 folara za kvartoč. ${ }^{224}$ Mato Georgio bio je tih godina najvažniji uvoznik ulja iz Bara. Stoga su se početkom prosinca 1398. gradske vlasti dogovorile s Matom da iz Bara doveze 300 stari ulja. Do kraja 1398. ponovo skače cijena, pa se tako do ožujka 1399. ulje prodaje po 28 folara za kvartoč. Porast cijene motivirao je trgovce da se zainteresiraju za nabavku ulja. Mato je u prvoj polovici ožujka 1399. obećao da će iz Bara za 9 dana dopremiti 200 stari ulja. Mogao je pola izvesti, a pola prodati u Gradu. Georgio je ulje za prodaju najčešće davao Baraninu Cnusu Petrovichu, koji je imao dućan u Gradu. ${ }^{225}$

Srebro je isto tako predstavljalo značajan artikl u dubrovačko-barskoj trgovini. $U$ dokumentima se spominje trgovina srebrom i srebrnim predmetima u Dubrovniku. Ivan Samuelis trgovao je srebrnim predmetima. U rujnu 1364. kupio je 25 libri laboreeii argenti. ${ }^{226}$ U ljeto 1377. Mirza Ratkovich iz Bara potvrđuje da je preuzeo, u ime Franka iz Bara, od dubrovačkog kancelara Ivana unam ladicam argenti, za koju je plaćeno 6 perpera i 4 groša. ${ }^{227}$ Sredinom prosinca 1390. dubrovački zlatar Pripčin obvezao se dati u roku od 15 dana Marinčetu Mirossiju tacia quator argenti (četiri srebrne zdjele). ${ }^{228}$ Početkom proljeća 1391. Martin i Pavel iz Bara potvrđuju prijem srebra od Dubrovčanina Sime Nikovicha. ${ }^{229}$

Tkanine su uz srebro bile popularan trgovački artikl. Bar je bio mjesto preko kojega su tkanine ulazile u Srbiju. Ivan Samuelis početkom prosinca 1365. uzeo je na zajam od Blaža Radovanova tkanine kao trgovačku robu. ${ }^{230} \mathrm{O}$ velikoj potražnji tkanina svjedoči i činjenica da je zetski gospodar Đurađ II. Balšić od dubrovačkih poklisara najčešće kao poklon dobivao skupocjene tkanine. ${ }^{231}$

222 Nella LONZA, Odluke dubrovačkih vijeća 1395-1397. Reformationes consiliorum civitatis Ragusii 1395-1397, Zagreb, Dubrovnik, 2011., 155 - 156; Vidjeti više o tome u: D. Dinić-KnEŽEvić, Trgovina uljem, 293 - 296, bilj. 73, 74.

223 I. Manken, Dubrovački I, 221.

224 D. Dinić-KneŽEvić, Trgovina uljem, 298.

225 D. Dinić-KneŽEvić, Trgovina uljem, 299 - 305.

226 L. Thallóczy, C. Jireček, E. Sufflay, Acta II, 48.

227 HR-DAD, Deb. Not., sv. 8, f. 57'v (8. 7. 1377.).

228 HR-DAD, Div. Canc., sv. 29, f. $162^{\prime}$ v (14. 12. 1390.).

229 HR-DAD, Div. Canc., sv. 29, f. 192v (25. 3. 1391.).

230 Pet godina kasnije Blaž Radovanov u kancelarijatu poništava Ivanov dug. HR-DAD, Div. Canc., sv. 22, f. 90v, (30.7. 1370.). 
Od alkoholnih pića srednjovjekovnog čovjeka vino se nalazilo na prvom mjestu. ${ }^{232}$ Trgovina ovim alkoholnim pićem zauzimala je značajno mjesto $u$ životu Grada. Vino se moglo kupiti i konzumirati u dubrovačkim krčmama. ${ }^{233}$ Statut Bara vjerojatno je sadržavao odredbu o zabrani prodaje stranog vina u Gradu. ${ }^{234}$ To bi moglo biti objašnjenje zašto se u dokumentima ovaj artikl i njegova prodaja ne spominje u Baru. U svega nekoliko vrela izravno se spominje trgovina ovim proizvodom. Ortonjani iz Abruzza dovozili su svoje bijelo vino $u$ Bar 1370. godine na prodaju. Krajem listopada 1390. u Dubrovniku je odlučeno izvesti 200 kvinkva vina u Bar ili Ulcinj. ${ }^{235}$

Iz Dubrovnika u Bar uvozio se građevinski materijal (crijep) za popravak crkava i stambenih zgrada. Početkom siječnja 1388. Malo vijeće dozvolilo je uvoz crijepa, bez plaćanja carine, za opatiju u Ratcu. ${ }^{236}$ U listopada 1396. ponovo je dozvoljeno ratačkom opatu da uveze 2000 crijepova. ${ }^{237}$ Građevinski materijal bio je potreban zbog sanacije crkve. Iz Bara se u Dubrovnik uvozio kamen. Sredinom ožujka 1397. dogovoreno je da dva klesara idu u Sv. Mariju na Ratcu rezati kamen potreban prokuratorima crkve sv. Blaža iz Dubrovnika. Klesari su se obvezali da će o svom trošku isporučiti u Dubrovnik lapides mille et ducentos de lapide rubeo..$^{238}$

\section{TRGOVAČKA DRUŠTVA}

U notarijatu i kancelarijatu nalaze se podatci o pojedinim Baranima koji su bili ortaci međusobno ili s dubrovačkim trgovcima. Oblik kroz koji se u Dubrovniku najčešće poslovalo jesu trgovačka društva. Udruživali su se sitniji i krupniji trgovci u kompanije koje su djelovale samo za jedno putovanje ili su niz godina imale razgranate poslove. Trgovačka društva nastajala su udruživanjem

231 Marijan Premović, Politički odnosi Đurađa II. Stracimirovića Balšića i Dubrovnika (1385. 1403.), Radovi Zavoda za povijesne znanosti HAZU u Zadru, sv. 60, 2018., 88, 90 - 91, 98, $101,115$.

232 Dušanka Dinić-Knežević, Trgovina vinom u Dubrovniku u XIV veku, Godišnjak Filozofskog fakulteta, sv. 19, Novi Sad, 1966., 83 - 84.

233 Gordan Ravančić, Život u krčmama srednjovjekovnog Dubrovnika, Zagreb, 2001., 22 - 23.

234 S. Marković, Stanovništvo, 644.

235 Vino se prodavalo na vjedra (quinqua, quinga, quincha) zapremnine od 21 litre. S. MARKović, Stanovništvo, 317, bilj. 1363.

236 Savo Marković, Benediktinska opatija sv. Marije Ratačke kod Bara: Acta diplomatica et iuridica, Croatica Christiana periodica, Vol. 28, No. 53, 2004., 192, 217; Katarina Mitrović, Benediktinci na području Barske nadbiskupije i Kotorske biskupije: (9. stoljeće - 1571), Kotor, 2015., 194 - 195.

237 N. LONZA, ODV 1395-1397, 136.

238 L. Thallóczy, C. Jireček, E. Sufflay, Acta II, 163. 
najmanje dvojice trgovaca. Bogatiji pojedinci mogli su ulagati svoja sredstva u veći broj društava. Najčešći oblik udruživanja u ovom razdoblju bila je kolegancija (collegantia). Prvi trgovac (socius stans) ostajalo bi u Dubrovniku, dok bi drugi (socius tractans) poslovao putujući u Bar, na zetsko ili albansko primorje. Prvi član društva ulagao bi $2 / 3$ kapitala, dok bi drugi partner unosio u društvo $1 / 3$ kapitala, svoj rad i znanje. Dobit bi članovi društava dijelili na jednake dijelove. ${ }^{239}$ Postojale su i drugačije podjele novčanih sredstava. Najbolji je primjer udruživanje u koleganciju barskog notara Ivana Merule i Marina Maracena. Oni su 23. travnja 1368. uložili po sto zlatnih dukata kojima će kupiti robu i prodati je u Baru. Od dobiti dva dijela pripadaju notaru Ivanu, a jedna trećina Andriji. ${ }^{240}$ Početkom prosinca 1382. Radoslav Dimitrovich (postolar) i Darko Ivanovich iz Bara ugovorili su poslovno udruženje. ${ }^{241}$ Trinaest godina kasnije Đuro Dobrasinovich iz Bara stupio je u koleganciju s Ratkom iz Lopuda, koji je bio iz dubrovačke dijeceze. Baranin je na raspolaganju imao 200 perpera s kojima je trebao trgovati, a trajanje poslovnog udruženja bilo je ograničeno na šest mjeseci. Dobit ili šteta trebale su se podijeliti na pola. ${ }^{242}$

Trgovačka kompanija (societas) podrazumijeva i više trgovaca, od kojih svatko u društvo ulaže novac ili svoj rad. Dobit ili gubitak u kompanijama ovisili su o visini novčanih sredstava i količini rada koje u društvo unose njihovi sudionici. Marinče (Marin) Miroseuich ugovorio je 22. kolovoza 1401. s vlasnikom barke Nikom i još tri mornara da međusobno formiraju societatem. Miroseuich je trebao uložiti u društvo 60 perpera, a mornari barku i trud. Ugovoreno je bilo da se trguje onom robom koja se mornarima učini najboljom i najprofitabilnijom. Nakon tri mjeseca mornari su se trebali financijski razračunati s Marinom i vratiti mu uloženi kapital te mu dati peti dio od zarade. Podjela je bila razmjerna jednakim dijelovima, a u slučaju štete princip bi bio isti. ${ }^{243} \mathrm{U}$ siječnju 1403. Marinče Miroseuich ponovo je sklopio ugovor $s$ patronom barke i tri mornara. Članovi društva procijenili su da

Statut grada Dubrovnika, 196 - 199, 402 - 403; Tomislav RAUKAR, Zadar u XV stoljeću: ekonomski razvoj i društveni odnosi, Zagreb, 1977., 268 - 274; Josip Lučić, Obrti i usluge u Dubrovniku do početka XIV stoljeća, Zagreb, 1979., 190; Tomislav RAUKAR, Splitska trgovačka društva XIV. stoljeća, Med Srednjo Evropo in Sredozemljem: Vojetov zbornik, ur. Sašo Jerše, Darjo Mihelič i Petar Štih, Ljubljana, 2006., 379 - 382; Ignacij VoJE, Prilog proučavanju dubrovačkih trgovačkih društava, Zbornik radova u čast akademiku Desanki Kovačević Kojić, ur. Rajko Kuzmanović, Dragoljub Mirjanić i Đuro Tošić, Banja Luka, 2015., 175 - 187.

240 HR-DAD, Deb. Not., sv. 7, f. 139v (23. 4. 1368.).

241 HR-DAD, Div. Canc., sv. 25, f. 156v (1. 12. 1382.).

${ }^{242}$ HR-DAD, Deb. Not., sv. 11, f. $119^{\prime}$ v (19. 2. 1395.).

${ }^{243}$ HR-DAD, Div. Canc., sv. 34, f. 11v (22. 8. 1401.). 
sklapanje novog ugovora o koleganciji može donijeti poslovnu korist. Novi kapital ponovo je uložen, a Marin je ovoga puta uložio 80 perpera (20 više). Mornarima je dao 15 perpera, a cilj je bio proširena reprodukcija uloženog novca. Barka je trebala ići na put i trgovati robom koja se mornarima činila najkorisnijom. Po završenom poslu Marinče je trebao dobiti nazad svoj dio kapitala i četvrti dio zarade. ${ }^{244}$ Udruživanje je donosilo korist i onome tko je vodio poslove i onome tko je ulagao novac. Nemamo podatke iz vrela kojom su robom trgovali. Najviše je društava sklopljeno na rok od jedne godine, ali ta odredba u ugovoru nije nužno značila da će društvo toliko i trajati.

\section{ZAKLJUČAK}

Nakon Zadarskog mira 1358. Dubrovnik ulazi u razdoblje pojačanog razvoja, postaje vrlo stabilan i nudi poticajan poslovni ambijent za dolazak trgovaca iz zaleđa i okolice. Veze između Dubrovnika i Bara jačaju od 1361. godine, kada Barani priznaju vlast zetskih gospodara Balšića. Balšići su 1361. postali dubrovački građani i politički partneri. To dovodi do snažne trgovačke suradnje i dobrih odnosa s Baranima. Time su stvoreni neophodni uvjeti za njihov brojniji dolazak u Dubrovnik i obavljanje trgovačkih aktivnosti. U radu je prikazano razdoblje od odlaska Mlečana s istočne obale Jadrana 1358. do 1405. i njihova povratka na južni Jadran i osvajanja komune Bar.

U Državnom arhivu u Dubrovniku iz fondova arhivskih serija Notarske zadužnice (Debita Notariae), Različiti spisi kancelarije (Diversa Cancellariae) i Različiti notarski spisi (Diversa Notariae) sakupili smo brojne razasute sitnije ili krupnije informacije o mikropovijesti kreditne trgovine Barana u Dubrovniku u naznačenom razdoblju. $U$ arhivskim se vrelima spominju mnogi Barani koji Grad dolaze u potrazi za zaradom. Poseban naglasak je na notarijatu, čije se isprave odnose na kreditne transakcije Barana u Gradu. Kroz kreditni aspekt poslovanja moguće je sagledati potrošačku moć Barana i njihovu uključenost u dubrovačku trgovinu. Svi kreditni poslovi koji premašuju vrijednost 10 perpera registrirani su kod javnog bilježnika i imali su karakter javne notarske isprave. Trgovci iz Bara koji su dolazili u Dubrovnik zaduživali su se kod dubrovačke vlastele i pučana. Kao kreditori iz reda vlastele najčešće se spominju rodovi Georgio, Sorgo, Palmota, Zrieva, Bona i Volçe. Najveći kreditor za Barane među dubrovačkim pučanima bio je Boganče Toloe. Iza kredita najčešće se krije trgovačka roba, koju 
bi potom dužnici plasirali na barsko, odnosno zetsko tržište, obvezujući se da će do određenog roka cjelokupan dug isplatiti u gotovom novcu. Zajam se najčešće davao na razdoblje od tri mjeseca. Kredit su dužnici dobivali na osnovu garancija jamca, jamstva prokuratora. Svi su oni najčešće bili iz Bara ili su poslovno surađivali s njima. Također, dobivali su kredit na temelju zaloga, koji je morao odgovarati vrijednosti kredita. U svim ugovorima kamata je iznosila $20 \%$, što znači da se na pozajmljenih 10 vraćalo 12 dinara.

Fokus rada je na poslovnom životu trgovaca, putnika i malih ljudi, koji su se stalnim ili privremenim boravkom u Gradu željeli obogatiti ili su se borili za preživljavanje. Najveći uspjeh u trgovini postigao je Džive Alexevich koji je u potrazi za zaradom ostvario najbolje poslovne veze te bio umrežen s Baranima, dubrovačkom vlastelom i pučanima. Kao došljak postao je domiciliran u Gradu (habitator), a imao je i dućan. Osim kao uspješan trgovac, iskazao se i kao vjerovnik. Kao stanovnici u Gradu upisani su članovi obitelj Petrovich. Uspješni i bogati barski trgovci (Đorđe, Marin Vidov Rigibat i Stano Hiliich) dobili su od dubrovačkih gradskih vlasti građanstvo (cives). Pripadnici barskih plemićkih rodova registrirani su kao zajmodavci. Na osnovi vrela prikazane su njihove trgovačke aktivnosti i genealogije. Neke obitelji i njihovi članovi bili su poslovno uspješni (Samuelis, Mauro, Goliebo, Luka Maçman, Bacan, Pasqualis, Marinče Miroseuich), a neki manje (Ruggi, Andrija Valentino, Maroje Nati, Marin Zare, Viciano, Teodor Modrocur). Upisani su u dokumentima kao stranci (forenses) i privremeno su boravili u Gradu zbog poslovnih aktivnosti. Vlasti barske komune uzimale su nekoliko puta novac na posudbu od Grada sv. Vlaha i njegovih istaknutijih trgovaca. To su najčešće potrošački zajmovi, za izlazak iz financijskih problema. Iz arhivskih vrela obrađeni su trgovci koji su jednom ili nekoliko puta uzeli kredit. Najveći broj njih bio je reda pučana (obrtnici i pomorci), a sudjelovali su u kreditnoj trgovini i njihova novčana zaduženja bila su skromnih razmjera.

Podatci iz notarijata su stereotipizirani, ali ako se povežu i slože u cjelinu, prikazuju dinamičnu sliku trgovačkih odnosa na relaciji između Dubrovnika i Bara (ili Zetskog primorja) i obrnuto (v. Grafikon 1). Prepoznali smo, prikazali i analizirali 171 dužnički ugovor Barana, kao i 27 kreditnih ugovora koje su dali kao vjerovnici. Opseg kreditnih zaduženja nije moguće sagledati u cjelini jer notarske knjige nisu sačuvane za pojedine godine (1370. 1378., 1382. - 1389. i 1397. - 1400.). Zaduženja Barana u Gradu možemo sagledati kroz dva razdoblja. Prvo razdoblje traje od 1358. do 1369. godine. To razdoblje predstavlja uspon u kreditnoj aktivnosti Barana. Poslije prelaska Dubrovnika pod vrhovnu zaštitu ugarsko-hrvatskog kralja već 1359. godine 
iznos zaduženja je 2.949 dukata (18 kredita). Broj kredita u prosjeku iznosi tada oko 12, a dobri politički odnosi sa zetskim gospodarima Balšićima utječu na povećanje kreditne aktivnosti. Najveći uspon kreditna trgovina dostiže 1369. godine. Ukupan iznos zaduženja bio je 3.761,5 dukata, a broj kreditnih ugovora bio je 17. Povećanju opsega pozajmljivanja pridonijela je povelja braće Balšić (17. siječnja 1368. na Mati), kojom su Dubrovčanima ukinuli carinu na Danju i jamčili im slobodu kretanja na svom teritoriju bez plaćanja carina i drugih smetnji. U drugom razdoblju, od 1380. do 1405., dolazi do smanjivanja intenziteta i vrijednosti kreditne trgovine. Sklopljeno je samo 21 zaduženje u Gradu, a iznos novca kreće se od 25 do 1.231 dukata.

Barani su se bavili prodajom i preprodajom trgovačke robe. Barska komuna bila je bogata maslinama i proizvodila je velike količine ulja. Zato su se trgovci usmjerili prema izvozu ulja u Grad, što je jamčilo uspjeh i dobar profit. Osim ulja, izvozili su žito iz albanskog primorja, kao i kamen. Trgovalo se i srebrom. Iz Grada trgovačku robu najčešće uzimaju u vidu kredita za tkanine i sol. Vjerujemo da se najveći broj kreditnih zaduženja u robi krije iza ovih artikala. Osim toga, uvozio se građevinski materijal (crijep) i vino u Bar. Da bi uspješnije poslovali, Barani se udružuju u trgovačka društva poznata kao kolegancije. Društva su predstavljala pouzdan oblik poslovanja, jer su se dobit ili šteta dijelili na pola.

Trgovina je u Dubrovniku privlačila sve kategorije stanovništva, koje su se, bez obzira na svoju struku, njome bavile. Barska trgovačka skupina imala je skromnije, ali kontinuirano sudjelovanje u gospodarskoj povijesti Grada sv. Vlaha. Barani su na osnovu povjerenja i uspješnosti dobivali trgovačke kredite, dok je materijalna dobit za Grad i njegove stanovnike utjecala na to da ih Dubrovnik podrži. 


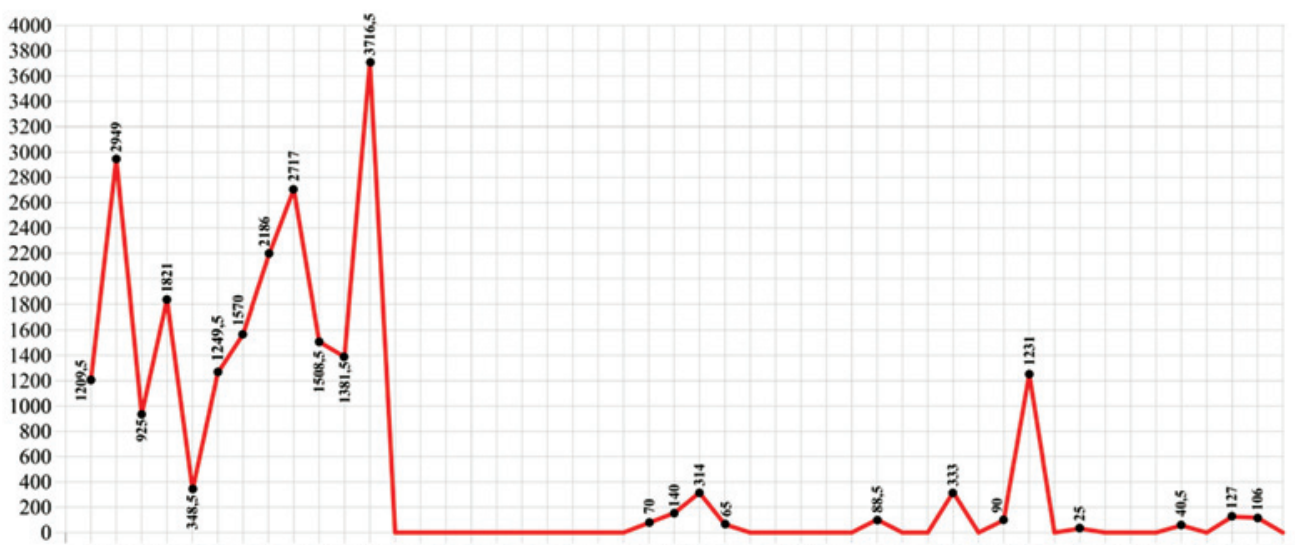

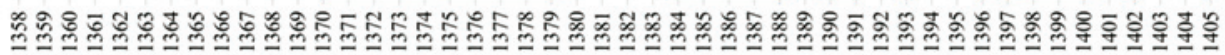

Grafikon 1. Zaduživanja Barana u dukatima

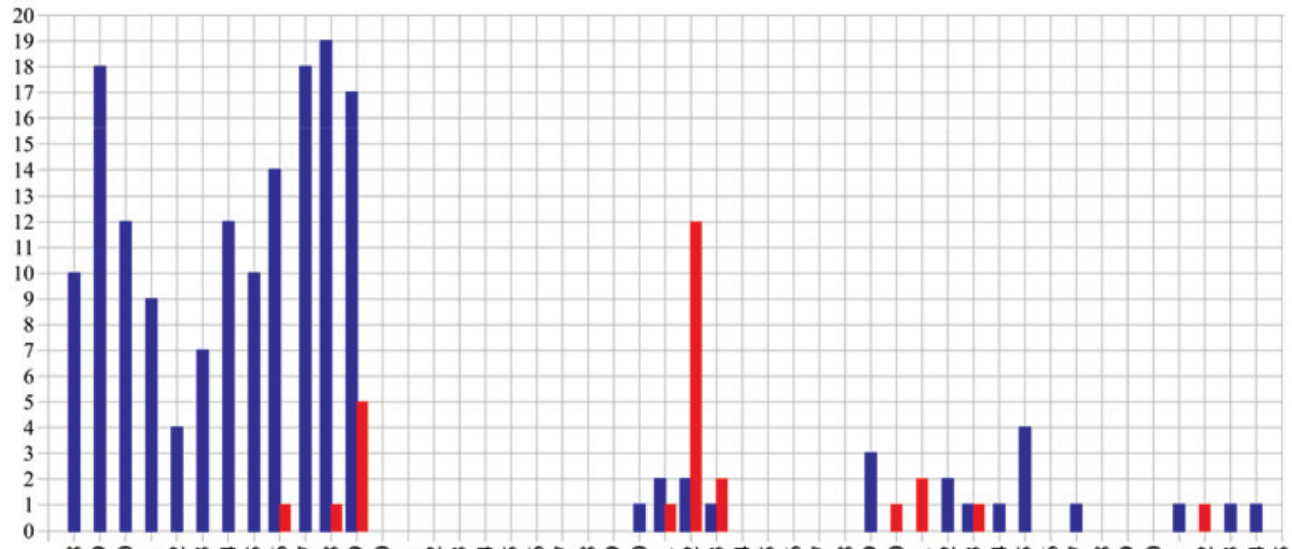

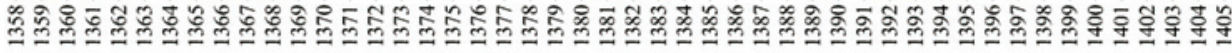

uzimanje kredita

- davanje kredita

Grafikon 2. Barani u Gradu sv. Vlaha - zajmovi i zajmodavci 


\section{IZVORI I LITERATURA}

\section{IZVORI:}

Hrvatska - Državni arhiv u Dubrovniku, Dubrovnik (HR-DAD), Diversa Cancellariae (Div. Canc.), ser. 35, sv. $19-35$.

HR-DAD, Debita Notariae (Deb. Not.), ser. 36, sv. 4 - 13.

HR-DAD, Diversa Notariae (Div. Not.), ser. 26, sv. 3 - 12.

HR-DAD, Testamenta Notariae, ser. 10, sv. 7.

\section{OBJAVLJENI IZVORI:}

Benyovs ky Latin, Irena, Zelić, Danko, Knjige nekretnina dubrovačke općine (13 - 18. st.), Vol. 1, Zagreb - Dubrovnik, 2007.

Dinić, J. Mihailo, Iz Dubrovačkog arbiva, knj. 1, Beograd, 1957.

Dinić, J. Mihailo, Odluke veća Dubrovačke republike, II, Beograd, 1964.

JIREČE K, Konstantin, Spomenici srpski, Spomenik SKA, sv. 11, Beograd, 1892.

KotrulJ, Benedikt, Libro del arte dela mercatura. Knjiga o vještini trgovanja, priredila i prevela Zdenka Janeković Römer, Zagreb - Dubrovnik, 2009.

Kurtović, Esad, Arhivska grada za historiju srednjovjekovne Bosne (Ispisi iz knjiga kancelarije Državnog arhiva u Dubrovniku 1341-1526), knj. 1, Sarajevo, 2019.

Lonza, Nella, ŠundricA, Zdravko, Odluke dubrovačkih vijeća 1390 - 1392, Zagreb - Dubrovnik, 2005.

Lonza, Nella, Odluke dubrovačkih vijeća 1395-1397. Reformationes consiliorum civitatis Ragusii 1395-1397, Zagreb, Dubrovnik, 2011.

Monumenta Ragusina: libri reformationum III, A. 1359. - 1364., Zagrabiae, 1895.

Rudić, Srđan, Povelja Balšića Dubrovčanima, Stari srpski arhiv, sv. 9, Beograd, 2010., 93 - 98.

Smičıklas, Tadija, Diplomatički zbornik Kraljevine Hrvatske, Dalmacije i Slavonije, sv. XV., Zagreb, 1934.

Statut grada Dubrovnika: sastavljen godine 1272., priredili i preveli Ante Šoljić, Zdravko Šundrica i Ivo Veselić, Dubrovnik, 2002.

Stojanović, Ljubomir, Povelje i pisma, I-1, Beograd, 1929.

Thallóczy, de Ludovicus, Jirečex, Constantinus, Sufflay, de Emilianus, Acta et diplomata res Albaniae mediae aetatis illustrantia II (annos 1344 - 1406 continents), Vindobonae (Beč), 1918. 


\section{LITERATURA:}

Antonović, Miloš, Grad i župa u Zetskom primorju i severnoj Albaniji u XIVi XVveku, Beograd, 2003.

BlažınA Tomić, Zlata, Kacamorti i kuga: utemeljenje i razvoj zdravstvene službe u Dubrovniku, Zagreb - Dubrovnik, 2007.

Božıć, Ivan, Ekonomski i društveni razvitak Dubrovnika u XIV - XV veku, Istorijski glasnik, sv. 1, Beograd, 1949., 21 - 61.

Boš Ković, Đurđe, Stari Bar, Beograd, 1962.

ČREMOŠNIK, Gregor, Dubrovačka kancelarija do god. 1300. i najstarije knjige dubrovačke arhive, Glasnik Zemaljskog muzeja u Bosni i Hercegovini, sv. 39/2, Sarajevo, 1927., $231-253$.

Ćirković, Sima, Hrabak, Bogumil, Damjanović, Nikola, Vujović, Đuro, Bar grad pod Rumijom, Bar, 1984.

Ćuk, Ruža, Porodica Stano iz Bara u srednjem veku, Istoriski zapisi, sv. 3/4, Podgorica, 1999., 17 - 25.

ĆuK, Ruža, Dubrovačka porodica Žaretić poreklom iz Bara u srednjem veku, Istoriski časopis, sv. 48, Beograd, 2001., 53 - 57.

DAnilović, Jelena, Zaloga u starom dubrovačkom pravu, Anali Pravnog fakulteta u Beogradu, sv. 35, br. 6, Beograd, 1987., 635 - 662.

Dinić, J. Mihailo, Dubrovački tributi, Iz srpske istorije srednjeg veka, ur. Sima Ćirković, Vlastimir Đokić, Beograd, 2003., 713 - 755.

Dinić-Knežević, Dušanka, Trgovina vinom u Dubrovniku u XIV veku, Godišnjak Filozofskog fakulteta, sv. 19, Novi Sad, 1966., 39 - 85.

Dinić-Knežević, Dušanka, Trgovina žitom u Dubrovniku u XIV veku, Godišnjak Filozofskog fakulteta, sv. 10, Novi Sad, 1967., 79 - 131.

Dinić-Knežević, Dušanka, Trgovina uljem u Dubrovniku u XIV veku, Historijski zbornik, god. XIII. - XIV, Zagreb, 1970. - 1971., 282 - 306.

Dinić-Knežević, Dušanka, Tkanine u privredi srednjovekovnog Dubrovnika, Beograd, 1982.

Dinić-Knežević, Dušanka, Dubrovnik i Ugarska u srednjem veku, Novi Sad, 1986.

Dinić-KNEŽEvić, Dušanka, Migracije stanovništva iz južnoslovenskih zemalja u Dubrovnik tokom srednjeg veka, Novi Sad, 1995.

Dinić-Knežević, Dušanka, Zetski primorski gradovi u svetlu dubrovačkih izvora, Srednjovjekovna istorija Crne Gore kao polje istraživanja, ur. Branislav Kovačević, Podgorica, 1999., 131 - 139. 
Foretić, Vinko, Dubrovački arhiv u srednjem vijeku, Anali Historijskog instituta Jugoslavenske akademije znanosti i umjetnosti u Dubrovniku, sv. 6 - 7, Dubrovnik, 1959., 315 - 336.

Foretić, Vinko, O Dubrovačkom arhivu, Arhivist, god. 19, br. 1, Beograd, 1969., $52-64$.

Foretić, Vinko, Povijest Dubrovnika do 1808. Deo 1, Od osnutka do 1526., Zagreb, 1980.

GrbavAC, Branka, Srednjovjekovni notarski formulari i njihovi sastavljači, Javni bilježnik, sv. 34, Zagreb, 2011., 33 - 38.

GrbAVAC, Branka, Iz prošlosti javnog notarijata - od notarskog bastardela do izdane isprave, Javni bilježnik, sv. 36, Zagreb, 2012., 61 - 68.

Harris, Robin, Povijest Dubrovnika, Zagreb, 2006.

HrabAK, Bogumil, Privreda Bara u XIV i XV veku, Srednjovjekovna istorija Crne Gore kao polje istraživanja, ur. Branislav Kovačević, Podgorica, 1999., 167 - 197.

JANEKović-Römer, Zdenka, Višegradski ugovor: temelj Dubrovačke Republike, Zagreb, 2003.

JANEKoviĆ-RöMER, Zdenka, Građani, stanovnici, podanici, stranci, inovjerci u srednjovjekovnom Dubrovniku, Raukarov zbornik: zbornik u čast Tomislava Raukara, ur. Neven Budak, Zagreb, 2005., 317 - 346.

JAneković-Römer, Zdenka, Georgius Scambe de Gostigna, habitator Ragusii olim de Arbo, uspješan Dubrovčanin bez građanskoga prava, 8. Istarski biennale, Artisani et mercatores: o obrtnicima $i$ trgovcima na jadranskom prostoru, ur. Marija Mogorović Crljenko i Elena Uljančić, Poreč, 2019., 9 - 22.

JIREČE K, Konstantin, Važnost Dubrovnika u trgovačkoj povijesti srednjega vijeka, Dubrovnik, 1915.

KREKIĆ, Bariša, Helias and Blasius de Radoano, ragusan merchants in the second half of the fourteenth century, Zbornik radova Vizantološkog instituta, sv. 41, Beograd, 2004., 399 - 422.

KovačEvić-Kojıć, Desanka, Priština u srednjem veku, Istoriski časopis, sv. 22, Beograd, 1975., $45-74$.

Lučıć, Josip, Pomorsko-trgovačke veze Dubrovnika s gradovima zetskog i dračkog primorja u XIII stoljeću, Pomorski zbornik, knj. 7, Zadar, 1969., 829 $-858$.

Lučić, Josip, Obrti i usluge u Dubrovniku do početka XIV stoljeća, Zagreb, 1979.

MANKEN, Irmgard, Dubrovački patricijat u XIV veku I, Beograd, 1960.

Manken, Irmgard, Dubrovački patricijat u XIV veku II: geneološke table, Beograd, 1960. 
Marković, Savo, Benediktinska opatija sv. Marije Ratačke kod Bara: Acta diplomatica et iuridica, Croatica Christiana periodica, vol. 28, No. 53, 2004., $183-234$.

MAR Ković, Savo, Notarijati medievalnih komuna crnogorskog primorja (odrazi antičkog nasljeđa, autonomnosti urbaniteta i humanističkog univerzalizma), Acta Histriae, sv. 18, br. 4, Koper, 2010., 823 - 846.

Marković, Savo, Barski patricijski rod Borisi u prošlosti: Jadran, Evropa, Mediteran, Povijesni prilozi, sv. 28, Zagreb, 2005., 71 - 105.

MARković, Savo, "U kriposti suetoga posluxa" - povijest barske patricijske familije Samuelis, Povijesni prilozi, sv. 37, Zagreb, 2009., 191 - 215.

Marković, Savo, Prilog proučavanju srednjovjekovne latinske leksike, epigrafike i socijalne morfologije Bara: Case Study Cyriacus, Istoriski zapisi, sv. 3/4, Podgorica 2013, 137 - 157.

Marković, Savo, Žare, Natalis, Dalmas: tri testamenta barskih patricija u Dubrovniku (XV - XVI v.), Arhivski zapisi, sv. 2, Cetinje, 2014., 31 - 60.

Marković, Savo, Barski patriciji Menze (Menče) - prilog poznavanju romanskoslovenske simbioze, Istraživanja, sv. 25, 2014., 89 - 109.

Marković, Savo, "Per discharigo della consciencia": Testamentarni odrazi medievalnog imaginarija barskog patricijskog roda Natalis (Nalis), Acta Histriae, sv. 3, 2014., 509 - 550.

Marković, Savo, Stanovništvo srednjovjekovnog Bara, Perast, 2014.

Marković, Savo, Baranke u Dubrovniku: Matična komuna u izjavama njihove posljednje volje (XIV. - XV. stoljeće), Povijesni prilozi, sv. 46, Zagreb, 2014., 7 - 46.

Marković, Savo, Jadranske trajektorije De Ruggiis, 8. Istarski biennale, Artisani et mercatores: o obrtnicima i trgovcima na jadranskom prostoru, ur. Marija Mogorović Crljenko i Elena Uljančić, Poreč, 2019., 118 - 143.

Martinović, J. Jovan, Socijalno - ekonomska struktura društva u Kotoru prve polovine XIV vijeka, Kotor, 2017.

MinaljČIĆ, Rade, Kraj Srpskog carstva, Beograd, 2001.

Mijušković, Jovanka Dodjeljivanje dubrovačkog građanstva u srednjem veku, Glas SANU, sv. 9, Beograd, 1961., 89-130.

Mitić, Ilija, Dubrovačka Republika i njezin arhiv - dva značajna fenomena evropske povijesti, Pomorski zbornik, sv. 23, Rijeka, 1985., 629 - 639.

Mitrović, Katarina, Benediktinci na području Barske nadbiskupije i Kotorske biskupije: (9. stoljeće-1571), Kotor, 2015.

Peršıč, Janez, Družina florentinskih bankirjev Soldanieri in Piran, Kronika, 25/1, Ljubljana, 1977., 12 - 18. 
PEŠORdA-VARdić, Zrinka, U predvorju vlasti. Dubrovački antunini u kasnom srednjem vijeku, Zagreb - Dubrovnik, 2012.

Premović, Marijan, Politički odnosi Đurađa II. Stracimirovića Balšića i Dubrovnika (1385. - 1403.), Radovi Zavoda za povijesne znanosti HAZU u Zadru, sv. 60, 2018., 85 - 117.

RAUKAR, Tomislav, Venecija i ekonomski razvoj Dalmacije u XV i XVI stoljeću, Zadarska revija, br. 3 - 4, Zadar, 1976., 177 - 184.

RAUKAR, Tomislav, Cives, habitatores, forenses $\mathrm{u}$ srednjovjekovnim dalmatinskim gradovima, Historijski zbornik, sv. 29 - 30, Zagreb, 1976. 1977., $139-149$.

RAUKAR, Tomislav, Zadar u XV stoljeću: ekonomski razvoj i društveni odnosi, Zagreb, 1977.

Raukar, Tomislav, Komunalna društva u Dalmaciji u XV. i u prvoj polovini XVI. stoljeća, Historijski zbornik, god. 23 - 24, Zagreb, 1980. - 1981., 139 209.

RAUKAR, Tomislav, Srednjovjekovne ekonomije i hrvatska društva, Zagreb, 2003.

RAUKAR, Tomislav, Splitska trgovačka društva XIV. stoljeća, Med Srednjo Evropo in Sredozemljem: Vojetov zbornik, ur. Sašo Jerše, Darjo Mihelič i Petar Štih, Ljubljana, 2006., 379 - 394.

Ravančić, Gordan, Život u krčmama srednjovjekovnog Dubrovnika, Zagreb, 2001.

REŠEtAR, Milan, Dubrovačka numizmatika I (bistorički) dio, Beograd, 1924.

REŠEtAR, Milan Dubrovačka numizmatika, II (Opisni) dio, Beograd, 1925.

Roller, Dragan, Dubrovački zanati u XV. i XVI. stoljeću, Zagreb, 1951.

ŠANJEK, Franjo, GRBAVAC, Branka i sur., Leksikon hrvatskoga srednjovjekovlja, Zagreb, 2017.

ŠEkularac, Božidar, Crna Gora u doba Balšića, Cetinje, 2012.

VEKARIĆ, Nenad, Vlastela grada Dubrovnika 1. Korijeni, struktura i razvoj dubrovačkog plemstva, Zagreb - Dubrovnik, 2012.

VE KARIĆ, Nenad, Vlastela grada Dubrovnika 2. Vlasteoski rodovi $(A-L)$, Zagreb - Dubrovnik, 2012.

VeKARIĆ, Nenad, Vlastela grada Dubrovnika 3. Vlasteoski rodovi $(M-Z)$, Zagreb - Dubrovnik, 2012.

VEKARIĆ, Nenad, Vlastela grada Dubrovnika 4. Odabrane biografije $(A-D)$, Zagreb - Dubrovnik, 2013.

VEKARIĆ, Nenad, Vlastela grada Dubrovnika 5. Odabrane biografije (E - Pe), Zagreb - Dubrovnik, 2014. 
Ve KARIĆ, Nenad, Vlastela grada Dubrovnika 7. Genealogije $(A-L)$, Zagreb Dubrovnik, 2016.

Ve KARIĆ, Nenad, Vlastela grada Dubrovnika 8. Genealogije $(M-Z)$, Zagreb Dubrovnik, 2017.

Vinaver, Vuk, Prilozi istoriji plemenitih metala, cena i nadnica (srednjovekovni Dubrovnik), Istoriski glasnik, sv. 1 - 2, Beograd, 1960., 51 - 94.

VoJe, Ignacij, Knjige zadolžnic: posebna notarska serija Dubrovniškega arhiva: univ. profesorju dr. Gregorju Čremošniku ob 10-letnici njegove smrti, Zgodovinski časopis, sv. XXII, br. 3 - 4, Ljubljana, 1968., 207 - 223.

VoJe, Ignacij, Kreditna trgovina u srednjovjekovnom Dubrovniku, Sarajevo, 1976.

VoJE, Ignacij, Poslovna uspešnost trgovcev v srednjeveškem Dubrovniku, Ljubljana, 2003.

VoJe, Ignacij, Prilog proučavanju dubrovačkih trgovačkih društava, Zbornik radova u čast akademiku Desanki Kovačević Kojić, ur. Rajko Kuzmanović, Dragoljub Mirjanić i Đuro Tošić, Banja Luka, 2015., 175 - 187. 
Marijan PREMOVIĆ

BAR MERCHANTS IN DUBROVNIK FROM 1358 UNTIL 1405

\section{SUMMARY}

Following the Zadar Peace Treaty in 1358, Dubrovnik entered a period of intensive development, became very stable, and provided a stimulating business environment for the arrival of merchants from the hinterland. Ties between the City and Bar had been strengthening since 1361 when Bar recognised the Zeta lords of the Balšić dynasty. In 1361, the Balšić noble family became citizens of Dubrovnik and political allies. That resulted in maximum trading stability and confidence in the citizens of Bar. The paper presents the period from the departure of the Venetians from the eastern Adriatic coast from 1358 to 1405 and their return to the South Adriatic, and the conquest of the commune of Bar.

From the archival series of Debita Notariae, Diversa Cancellariae and Diversa Notariae in the State Archives in Dubrovnik, we collected numerous scattered information on the micro-history of credit trade of Bar residents in Dubrovnik in the said period. The sources show increased interest of Bar residents in the credit affairs in the City. The credit aspect of the business enables an overview of the consumer power of Bar residents and their involvement in the Dubrovnik trade. Merchants from Bar who came to Dubrovnik borrowed from the nobility and commoners of Dubrovnik. The loan was usually granted for three months. The debtors were given the loan based on the guarantor and the procurator guarantees. They also received loans based on pledges. In all contracts, the interest rate was $20 \%$.

We identified, presented, and analysed 171 debt agreements of Bar residents and 27 credit agreements made of creditors selling and reselling. The loans of Bar residents from the City can be followed through two distinct periods. The first period from 1358 to 1369 shows the upward trend in Bar residents' credit activity. In the second period, from 1380 to 1405 , the intensity and value of the credit trade were on the decline. Bar residents were reselling the merchandise. The Bar Commune was rich in olives and produced large quantities of oil. For that reason, merchants focused on the exports of oil to the City, which guaranteed success and profit. In addition to oil, they exported grains from the Albanian coast, as well as stone. Silver was traded, as well. The merchandise most frequently taken on loan from the City were fabrics and salt. We believe that most of the credit indebtedness in merchandise was hidden behind these products. Furthermore, construction material and wine were imported to Bar. In order to make business 
more successful, the Bar residents formed trading partnership trading companies known as collegantia.

Trade in Dubrovnik attracted all population categories that engaged in commerce, regardless of their core profession. The participation of the traders' group of Bar in the economic history of the City of St. Blaise, though modest, was continuous. Bar residents were granted trade loans on the basis of trust and success, while the material gain for the City and its residents encouraged Dubrovnik to support them.

Key words: Bar, Dubrovnik, credit trade, trade products, trade companies, $14^{\text {th }}$ century. 
